\title{
Nowożytne piece do wypalania ceramiki budowlanej z okolicy Płońska
}

\section{Post-medieval kilns for firing construction ceramics from the area of Plońsk}

Zarys treści. W artykule zaprezentowano nowożytne piece do wypalania ceramiki budowlanej odkryte w okolicy Płońska; opisano ich konstrukcję i fazy użytkowania oraz proces produkcji. Ponadto zaprezentowano znaleziska pozyskane z wnętrza i sąsiedztwa pieców - fragmenty dachówek gąsiorkowych zwanych mnich-mniszka. Na podstawie danych ze źródeł pisanych i zabytków ruchomych określono prawdopodobny czas funkcjonowania wytwórni i potencjalnych odbiorców wytwarzanych tu wyrobów. Zaprezentowano informacje o innych tego rodzaju urządzeniach znanych z terenu Polski i Europy.

Slowa kluczowe: ceramika budowlana, piec do wypalania ceramiki budowlanej, dachówki, Płońsk, Mazowsze, nowożytność.

Przedmiotem opracowania są pozostałości warsztatu wytwarzającego ceramikę budowlaną. Składały się na niego relikty dwóch pieców, a także kilkadziesiąt obiektów archeologicznych zawierających fragmenty destruktów - odpadów produkcyjnych (w większości ułamków dachówek) oraz gruz ceglany. Z tego miejsca pozyskano też wiele innych materiałów źródłowych z późnego średniowiecza i nowożytności - głównie naczyń ceramicznych, a także kafli garnkowych i miskowych oraz pojedyncze wyroby metalowe. W rejonie pieców zarejestrowano również wyrobiska po eksploatacji gliny, tzw. glinianki i miejsca składowania gotowych wyrobów ${ }^{1}$.

${ }^{1}$ Przy opracowaniu pieców produkcyjnych z okolicy Płońska wykorzystałem sprawozdania z prac archeologicznych (Bednarczyk, Sujecka, Janicki 2008). Za udostępnienie maszynopisu dziękuję jego Autorom. 
Piece odsłonięto podczas badań archeologicznych prowadzonych w latach 2006-2008 na stanowisku 7 (AZP 48-60) w okolicy Płońska (ryc. 1), w województwie mazowieckim, na południowym brzegu rzeki Płonki. Pracami kierował dr Józef Bednarczyk z ramienia Stowarzyszenia Naukowego Archeologów Polskich Oddział w Warszawie, na zlecenie Generalnej Dyrekcji Dróg Krajowych i Autostrad. Prace archeologiczne związane były z przebudową drogi krajowej A7 prowadzącej z Warszawy do Gdańska. Na obszernym, ponad 72-arowym stanowisku, w toku prac badawczych wyróżniono dwie strefy osadnictwa, zróżnicowane pod względem zagospodarowania i czasu użytkowania. Starsza, zlokalizowana na kulminacji i częściowo krawędzi wyniesienia, związana była z kulturami łużycką, przeworską i wielbarską, a młodsza - na dnie doliny, przy obecnym korycie rzeki, funkcjonowała od wczesnego średniowiecza po czasy nowożytne. To właśnie w tej drugiej strefie natrafiono na relikty pieców. Pozostałości tych urządzeń zachowały się w niewielkim stopniu z powodu intensywnej działalności rolniczej prowadzonej na tym terenie (ryc. 2).

\section{Pozostałości warsztatu produkcyjnego}

Piece to dwa prostokątne w zarysie obiekty o zróżnicowanej wielkości, które stykały się ze sobą jedną z dłuższych ścian. Zorientowane były w przybliżeniu na osi północ-południe. W planie czytelny był cały ich zarys, w przekroju pionowym pozostały dwie, maksymalnie trzy warstwy cegieł i relikty kamiennych fundamentów (ryc. 3).

Większy piec - nr I - miał wymiary zewnętrzne: 4,85 m długości na 4,40 m szerokości, mniejszy - nr II - 4,20 m długości i 2,40 m szerokości i był dostawiony do wschodniej ściany większego urządzenia (ryc. 4). Wymiary wewnątrz komory pieca nr I wynosiły 4,30 m długości i 3,35 m szerokości, zaś pieca nr II - odpowiednio: 3,70 m na 1,8 m. Fundamenty obu urządzeń wykonano z różnej wielkości granitowych kamieni narzutowych o średnicach od 0,1 do 0,5 m. Grubość zachowanych ścian wynosiła od 0,4 do 0,5 m. W komorach piecowych zachowały się szczątkowo lica murów wykonanych z cegieł palcówek, natomiast od strony zewnętrznej odsłonięto kamienne fundamenty wkopane w piasek calcowy.

Piece, poza wielkością, różniły się też konstrukcją. Większy (nr I) miał dwie komory paleniskowe i trzy ceglane ławy służące do układania surówki, czyli uformowanych cegieł bądź dachówek przeznaczonych do wypalenia. Ławy znajdowały się wzdłuż dłuższych ścian pieca i w jego środkowej części. Ich szerokość była zbliżona i wynosiła 0,7-0,8 m. Umożliwiało to ustawienie na nich co najmniej dwóch rzędów cegieł (ryc. 5). Od strony palenisk lico ław wykonano z cegieł kładzionych na dłuższych, węższych krawędziach, w pozostałej części układano je płasko (w jednym lub w dwóch rzędach), miejscami na dłuższych krawędziach. 


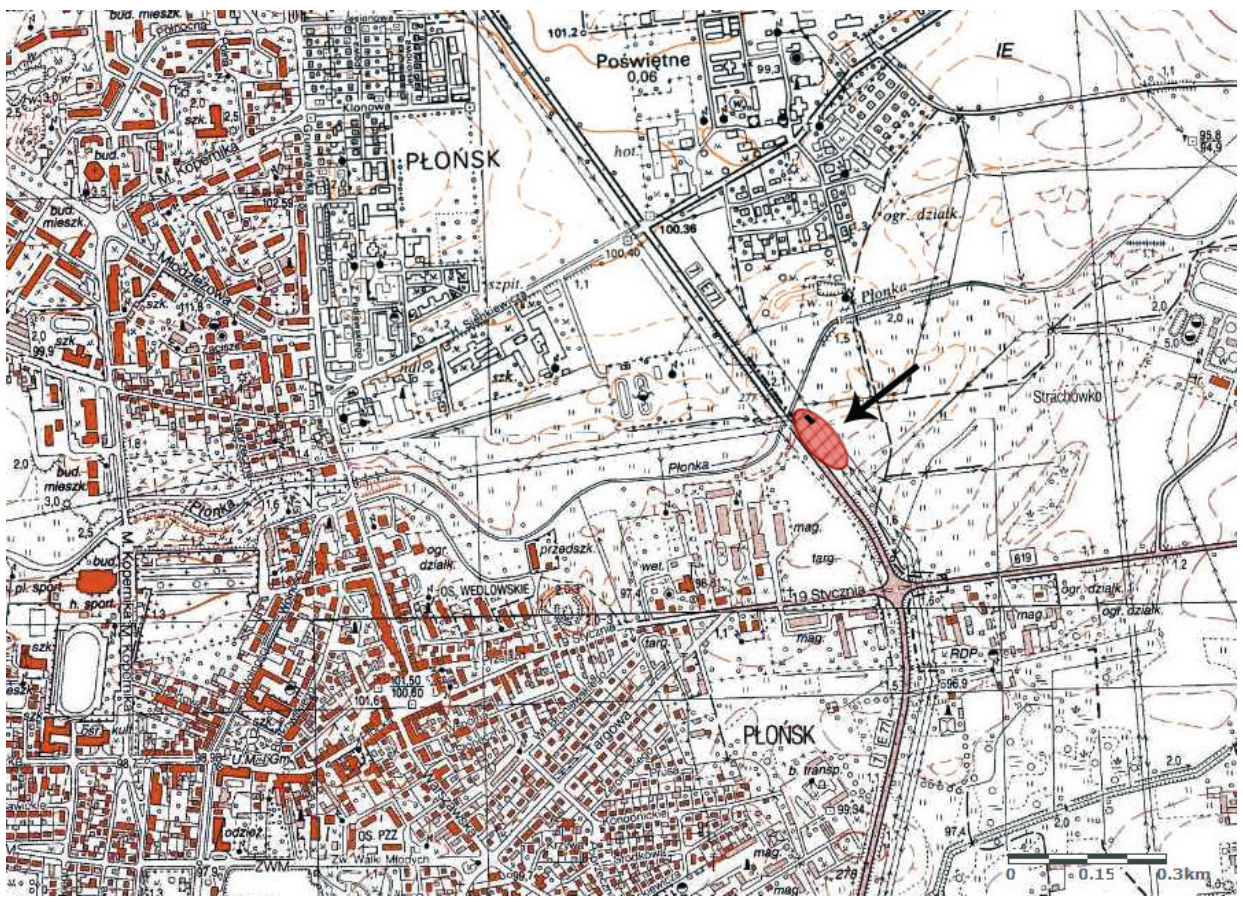

Ryc. 1. Płońsk, woj. mazowieckie. Fragment mapy topograficznej okolicy miasta z lokalizacją stanowiska archeologicznego i miejscem odsłonięcia reliktów pieców (kolor czarny) (wg geoportal.gov.pl.; oprac. W. Bis)

Fig. 1. Płońsk, Mazovian Voivodeship. Fragment of a topographic map of the town area with the location of the archaeological site and the place of kilns remains disclosure (black) (after geoportal.gov.pl.; edited by W. Bis)

W tak rozplanowanym wnętrzu pieca powstały dwa paleniska o szerokości 0,6 m, przebiegające przez całą jego długość. W piecu nr I przy wlocie i na końcu paleniska 1 odsłonięto ceglaną posadzkę wykonaną z przepalonych, płasko kładzionych cegieł. Spoiwem zastosowanym przy budowie ścian tego pieca była glina z dużą zawartością gruboziarnistego piasku.

Piec nr II miał jedno palenisko umieszczone w środkowej części, zagłębione około 0,15 m w stosunku do ław. Szerokość paleniska wynosiła - tak jak w przypadku pieca nr I - 0,6 m. Na podstawie jego konstrukcji stwierdzono, że było to urządzenie dwufazowe (ryc. 6). Pierwotnie służyło do wypalania kamieni wapiennych i konstrukcyjnie różniło się od pieca nr I. Nad paleniskiem pieca nr II wykonano prawdopodobnie sześć ceglanych łęków w odstępie 0,25-0,30 m od siebie. Zachowało się pięć ceglanych podstaw pod łęki dzięki czemu zrekonstruowano ich liczbę (ryc. 7). Ich szerokość była równa długości użytej do budowy cegły, około 0,27 m, zaś rozpiętość wewnętrzna łęków wynosiła około 0,6 m. Tworzyły one rodzaj rusztu, na którym układano kamienie 


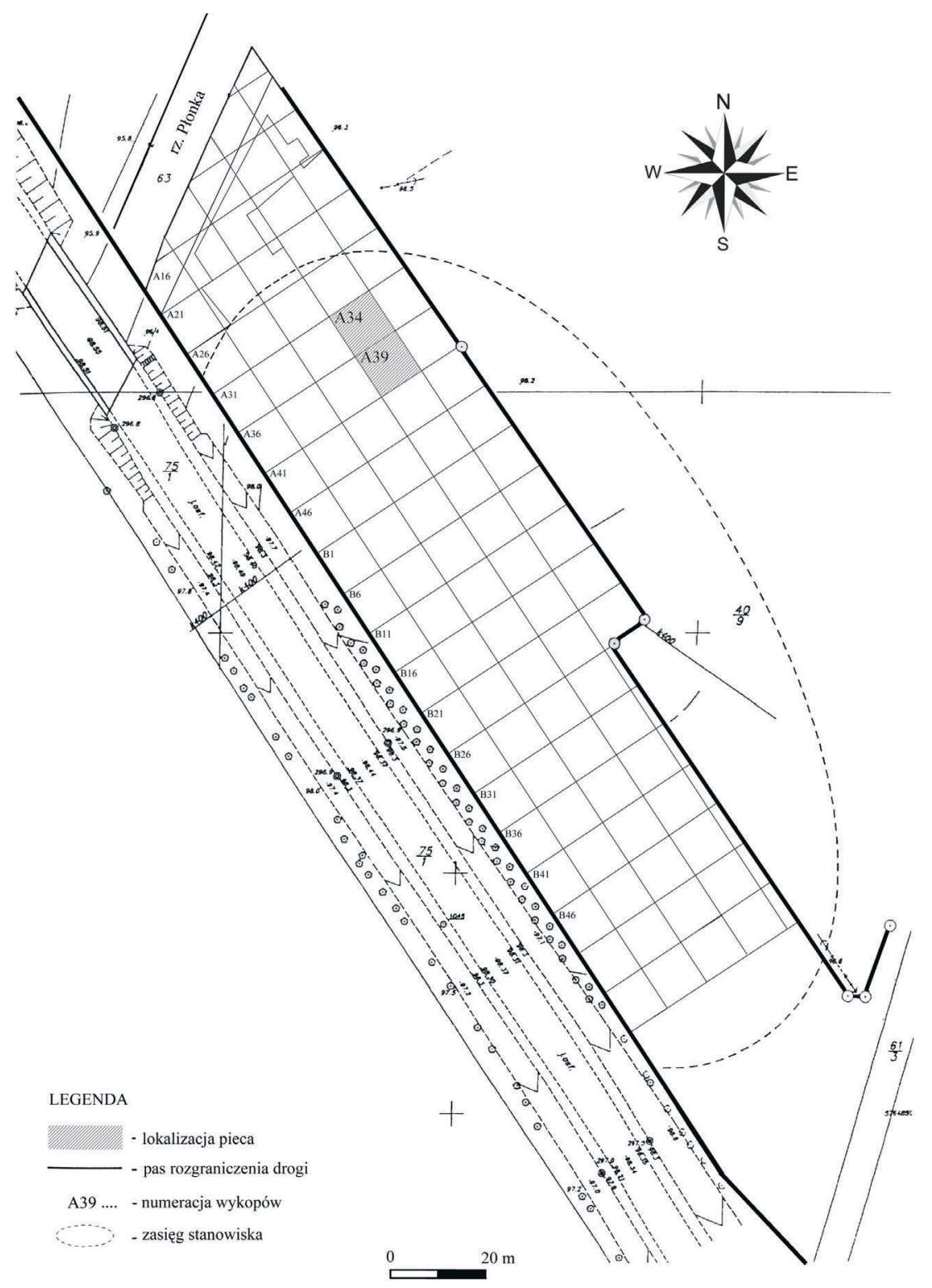

Ryc. 2. Płońsk, stanowisko 7, woj. mazowieckie. Plan stanowiska archeologicznego z rozmieszczeniem wykopów badawczych i lokalizacją terenu z reliktami pieców (wg Bednarczyk, Sujecka, Janicki 2008; oprac. W. Bis)

Fig. 2. Płońsk, site 7, Mazovian Voivodeship. Plan of archaeological site with arrangement of trenches and location of the area with kilns remains (after Bednarczyk, Sujecka, Janicki 2008; edited by W. Bis) 


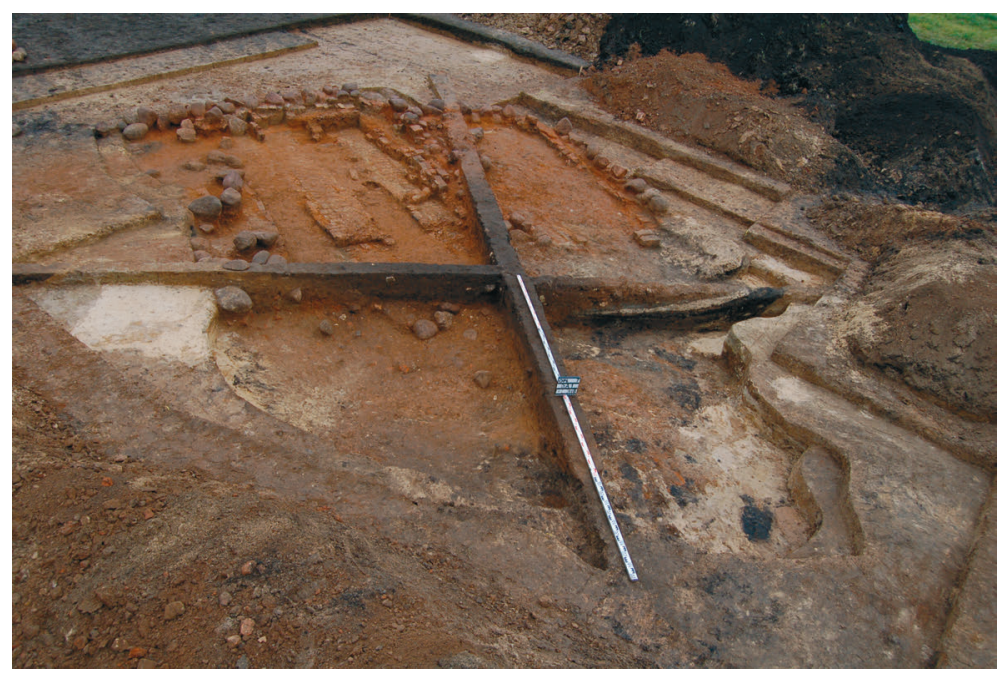

Ryc. 3. Płońsk, stanowisko 7, woj. mazowieckie. Widok od południa na relikty pieców w trakcie eksploracji (fot. J. Koralewska)

Fig. 3. Płońsk, site 7, Mazovian Voivodeship. View from the south to the kilns remains during exploration (photo by J. Koralewska)

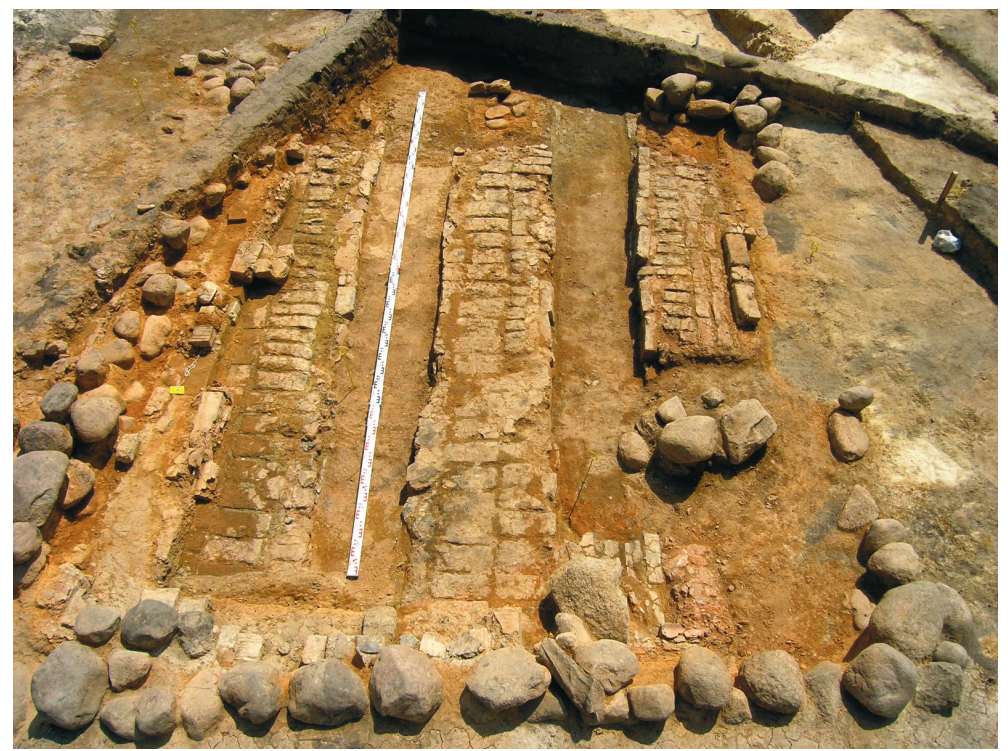

Ryc. 4. Płońsk, stanowisko 7, woj. mazowieckie. Widok od północy na relikty pieców I i II (fot. K. Janicki)

Fig. 4. Płońsk, site 7, Mazovian Voivodeship. View from the north to the remains of kilns I and II (photo by K. Janicki) 


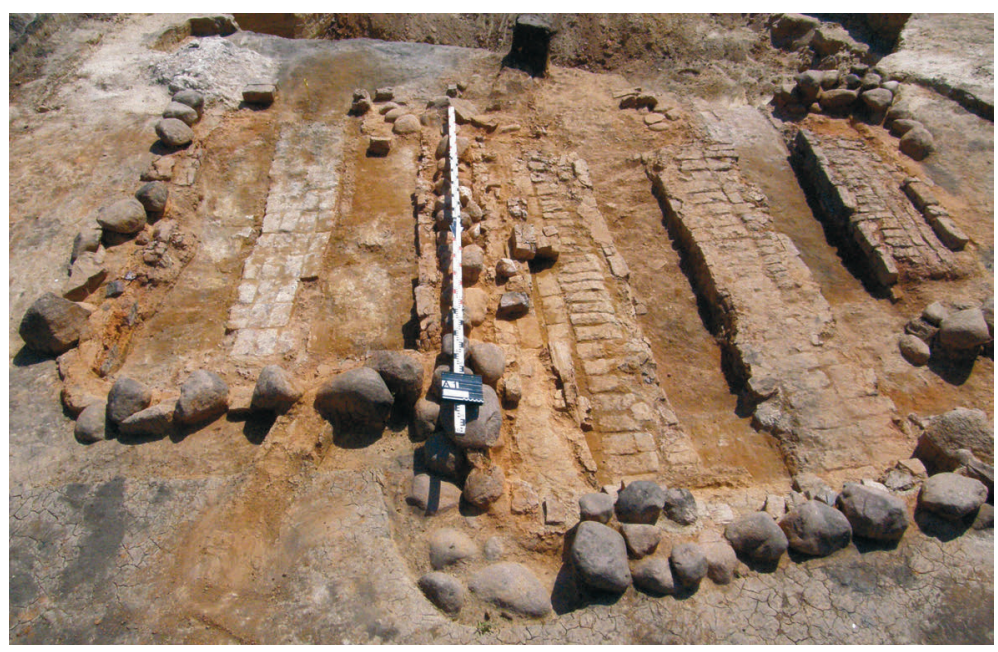

Ryc. 5. Płońsk, stanowisko 7, woj. mazowieckie. Widok od północy na relikty pieca I (fot. M. Kiona-Podhajny)

Fig. 5. Płońsk, site 7, Mazovian Voivodeship. View from the north to the remains of kiln I (photo by M. Kiona-Podhajny)

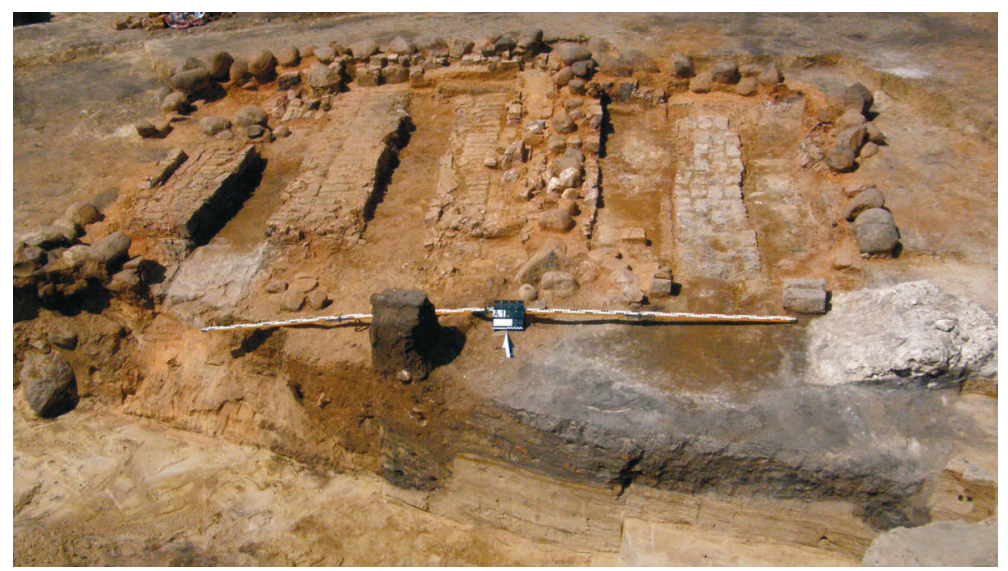

Ryc. 6. Płońsk, stanowisko 7, woj. mazowieckie. Widok od południa na pozostałości pieców I i II oraz jamę przypiecową (fot. K. Janicki)

Fig. 6. Płońsk, site 7, Mazovian Voivodeship. View from the south on the remains of kilns I and II and the adjacent pit (photo by K. Janicki)

wapienne przeznaczone do wypalenia. We wnętrzu pieca, w komorze paleniskowej, oraz w najbliższym sąsiedztwie urządzenia, a także przy otworze wlotowym do paleniska, odsłonięto skupiska wapna, destrukty kamienne i odpady poprodukcyjne. Mogą one potwierdzać przyjętą, pierwotną funkcję tego urządzenia (ryc. 8). 


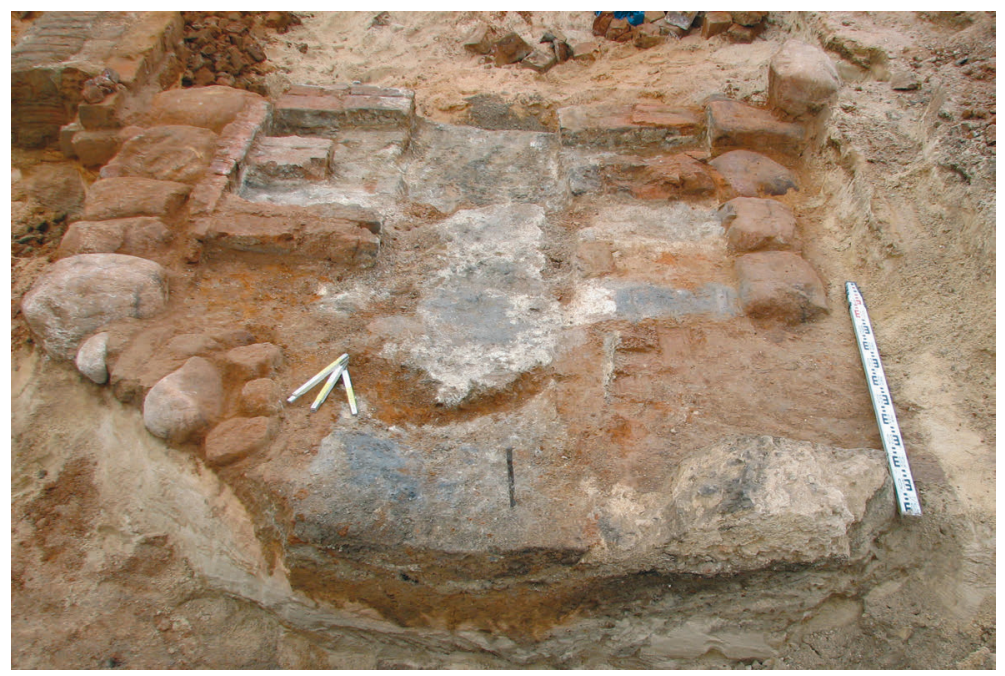

Ryc. 7. Płońsk, stanowisko 7, woj. mazowieckie. Widok od południa na piec II, widoczne podstawy łęków ceglanych (fot. M. Kiona-Podhajny)

Fig. 7. Płońsk, site 7, Mazovian Voivodeship. View from the south to the kiln II, visible bases of brick arches (photo by M. Kiona-Podhajny)

W drugim etapie użytkowania opisywanego pieca nastąpiła jego przebudowa i zmiana przeznaczenia, tzn. do wypału ceramiki budowlanej. O modernizacji świadczą: usunięcie ceglanych łęków, nieznaczne podniesienie (o około 0,15 m) poziomu dna pieca, wyłożenie paleniska cegłami kładzionymi płasko na całej długości urządzenia, bezpośrednio na pozostałościach i destruktach związanych z wypalaniem wapna. Dzięki temu zabiegowi po obu stronach dłuższych ścian powstały dwie ławy przeznaczone do układania surówki. Wykonano je z gruzu ceglanego zmieszanego z gliną, tworząc równe klepisko (ryc. 9).

Nie wiadomo, jak wyglądała górna część konstrukcji obu pieców, tzn. ich wysokość, sposób budowy ścian i zadaszenie. Prawdopodobnie, jak inne tego rodzaju urządzenia, nie były one przesklepione. Umożliwiało to łatwe i szybkie ich załadowanie oraz rozładowanie od góry. Po ułożeniu surówki piece były zapewne uszczelniane gliną, ziemią i destruktami pozostałymi z poprzednich wypałów, tworzącymi pokrywę (zamknięcie). W takim prowizorycznym sklepieniu pozostawiano otwory służące do odprowadzania spalin i do regulowania temperatury w trakcie wypalania. Jak podają źródła pisane, nad tak wybudowanymi piecami wykonywano jeszcze prowizoryczny dach dla ochrony przed zamoknięciem urządzenia (Arszyński 1970, s. 64-65). Tego rodzaju konstrukcje znane są również z XVI- i XVII-wiecznych źródeł ikonograficznych prezentujących wytwórnie ceramiki budowlanej (ryc. 10,11). W rejonie opisywanych obiektów nie stwierdzono jednak reliktów zadaszenia. 


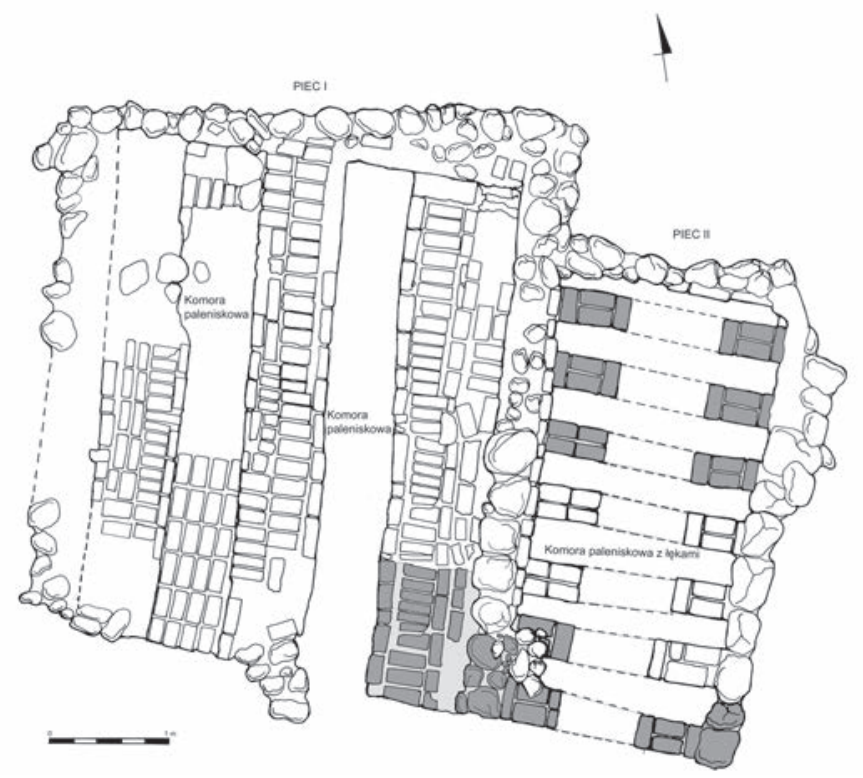

Ryc. 8. Płońsk, stanowisko 7, woj. mazowieckie. Rzut poziomy przyziemia pieców do wypalania ceramiki budowlanej (piec I) i kamieni wapiennych (piec II) w pierwszej fazie użytkowania. Kolorem szarym i linią przerywaną oznaczono zrekonstruowane rysunkowo elementy urządzenia (oprac. W. Bis)

Fig. 8. Płońsk, site 7, Mazovian Voivodeship. Plan of footing of kilns for firing construction ceramics (kiln I) and limestone (kiln II) in the first phase of use. By grey and dotted line were marked reconstructed elements of the device (edited by W. Bis)

Po południowej stronie pieców natrafiono na znacznych rozmiarów jamę przypiecową, zagłębioną w calec, o miąższości wypełniska do 1,30 m. Kształtem była zbliżona do półkola, o promieniu około $3 \mathrm{~m}$. Prawdopodobnie z jej wnętrza obsługiwano paleniska obu urządzeń. W wypełnisku jamy zalegał popiół wygarniany z pieców, miał ceglany, grudy wapna oraz fragmenty dachówek i cegieł.

Poza piecami i jamą przypiecową na badanym stanowisku odsłonięto łącznie 62 obiekty o różnym stanie zachowania, datowane - na podstawie pozyskanych z nich ruchomych znalezisk - na późne średniowiecze i czasy nowożytne. Na podstawie form i analizy zawartości wypełnisk podzielono je na kilka grup funkcjonalnych ${ }^{2}$. Najliczniejszą stanowiły jamy gospodarcze (33), następnie wyrobiska gliny (20), dołki posłupowe (6) i paleniska (3). Sześć jam usytuowanych

\footnotetext{
${ }^{2}$ Ze względu na przygotowywane pod redakcją Józefa Bednarczyka kompleksowe, monograficzne opracowanie wyników badań tego stanowiska w niniejszym artykule skupiono się jedynie na prezentacji samych pieców produkcyjnych i odpadów produkcyjnych powstałych w trakcie ich użytkowania. Pominięto szczegółowe opisy obiektów i ruchomych materiałów źródłowych, chronologicznie związanych z działalnością wytwórni ceramiki budowlanej, ograniczając się jedynie do podania najistotniejszych danych.
} 


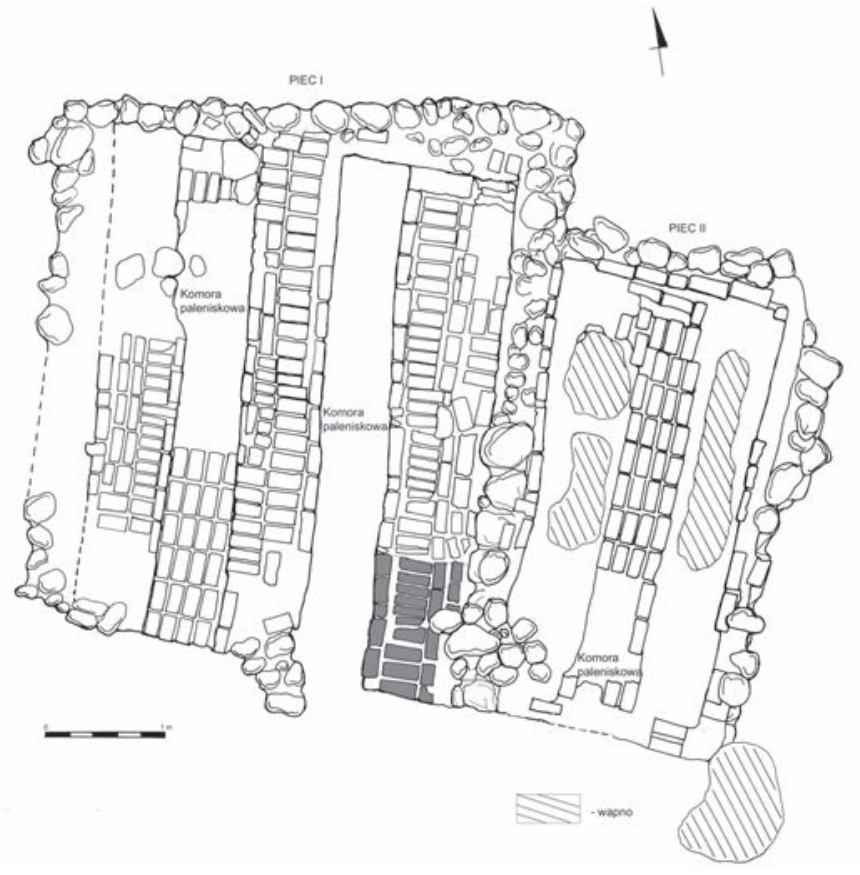

Ryc. 9. Płońsk, stanowisko 7, woj. mazowieckie. Rzut poziomy przyziemia pieców do wypalania ceramiki budowlanej w drugiej fazie użytkowania. Kolorem szarym i linią przerywaną oznaczono zrekonstruowane rysunkowo elementy urządzenia (oprac. W. Bis)

Fig. 9. Płońsk, site 7, Mazovian Voivodeship. Plan of footing of kilns for firing construction ceramics in the second phase of use. By grey and dotted line were marked reconstructed elements of the device (edited by W. Bis)

w pobliżu reliktów pieców uznano za funkcjonalnie związane z tymi urządzeniami, pozostałe - z trudną do uściślenia działalnością u schyłku średniowiecza i w okresie nowożytnym. We wnętrzu większości z nich znaleziono ułamki naczyń ceramicznych (przeważnie było ich po kilka, rzadziej kilkadziesiąt). Z niektórych pozyskano też inne znaleziska, takie jak fragmenty dachówek, cegieł, wyrobów żelaznych (ułamki noży, gwoździ) i szczątki zwierzęce.

Drugą, liczną grupę obiektów, stanowiły wyrobiska gliny (glinianki). W zdecydowanej większości były to obiekty znacznych rozmiarów, tworzące podłużne rowy. Ich długość wynosiła na ogół około 5 m, maksymalnie blisko 35 m, zaś szerokość wahała się między 3 a $4 \mathrm{~m}$, miąższość sięgała do $1 \mathrm{~m}$. Wypełniska w większości były wielowarstwowe, stanowiły je sekwencje warstw czarnej próchnicy zawierającej domieszkę gliny, piasku, niekiedy gruzu ceglanego. Wszystkie te obiekty to pozostałości po miejscach dawnej eksploatacji gliny, przeznaczonej zapewne do celów produkcyjnych lub budowlanych. W wypełniskach większości 


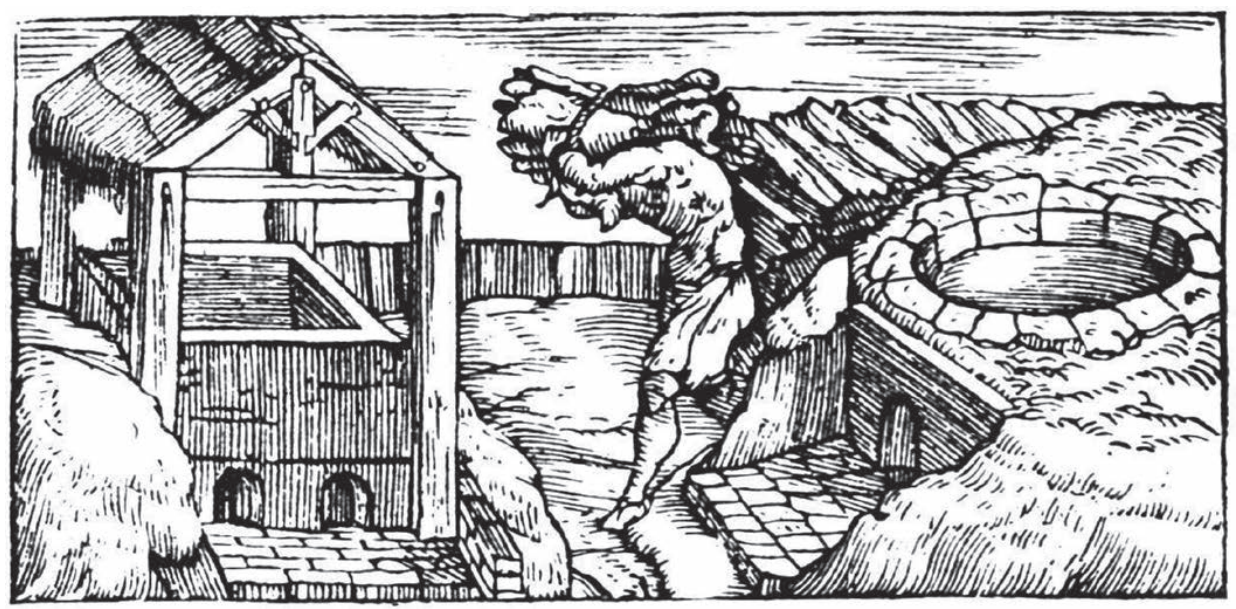

Ryc. 10. Produkcja cegieł przedstawiona na miedziorycie z 1540 roku, Włochy (wg Jakab 2005)

Fig. 10. Bricks production presented on a copperplate from 1540, Italy (after Jakab 2005)

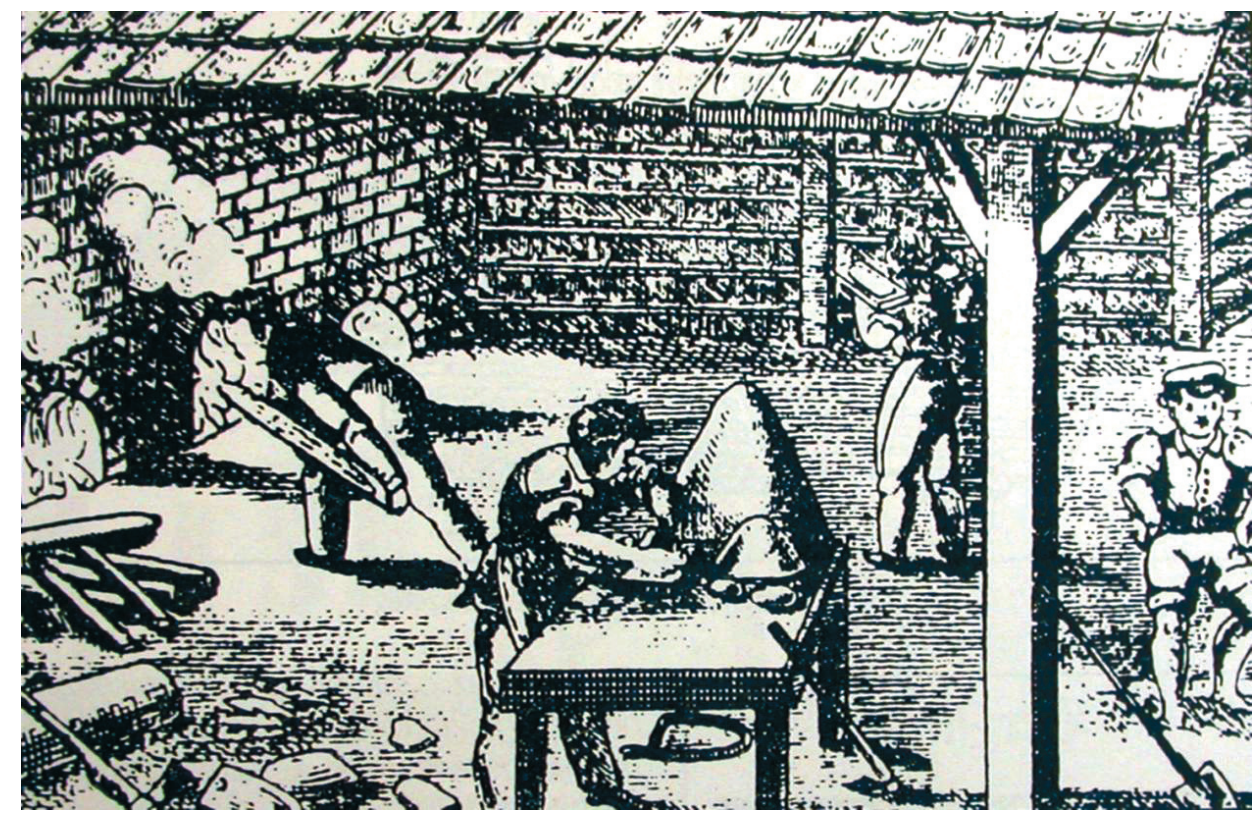

Ryc. 11. Wygląd XVII-wiecznej cegielni według Jana Amosa Komeńskiego (wg Buzás 1995)

Fig. 11. The appearance of a $17^{\text {th }}$-century brickyard after John Amos Comenius (after Buzás 1995) 
glinianek znaleziono materiały ruchome (od kilku do ponad 400 sztuk), przede wszystkim ułamki naczyń ceramicznych. Najliczniejsze (2041 sztuk) pozyskano z glinianki o największych rozmiarach - oprócz dominujących fragmentów naczyń (1631 sztuk), także kości zwierzęce i różnej wielkości fragmenty dachówek oraz kilka wyrobów z żelaza. Charakter wypełnisk opisywanych obiektów wskazuje, że glinianki użytkowano wtórnie jako doły śmietniskowe. Zostały one zapewne zasypane podczas późniejszych, prowadzonych tu prac niwelacyjnych, poprzedzających przeznaczenie terenu pod uprawy.

W profilach glinianek zachowały się nieznacznej grubości warstewki gliny, będące pozostałościami eksploatowanego pierwotnie surowca. Jej pokłady były niewielkie, ale stwierdzono, że glina charakteryzowała się plastycznością oraz mała ilością zanieczyszczeń organicznych i mineralnych. W wyniku badań geologiczno-morfologicznych w okolicy Płońska odnotowano zasobne pokłady tego surowca, nadającego się do produkcji cegieł, natomiast znacznie mniejsze złoża piasku (Smuda 1983, s. 9-10). Poświadczają to lokalizacje cegielni w pobliżu tego miasta, przedstawione między innymi na odręcznym planie terenów przedmiejskich sporządzonym w 1828 roku, gdzie odnotowano też usytuowanie domu strycharza (Bartoszewicz 2003, s. 178) oraz na mapie kwatermistrzowskiej wydanej w połowie XIX wieku³.

Wśród obiektów późnośredniowiecznych i nowożytnych zarejestrowano również sześć dołków posłupowych o zbliżonych rozmiarach, ich średnice wynosiły 0,3-0,4 m. W wypełniskach znalazły się warstwy jednorodne - glina, brunatna i czarna próchnica. Cztery dołki towarzyszyły dużej, czworobocznej jamie gospodarczej o wymiarach 1,9×1,9 m i miąższości 0,18 m. Znajdowały się w jej narożnikach i zapewne były pozostałościami konstrukcji ścian stojącego tu niegdyś budynku. W jamie znaleziono ułamki dachówek i cegieł. Relikty te zarejestrowano na wschód od jamy przypiecowej (w odległości około $5 \mathrm{~m}$ ). Przeznaczenie pozostałych dołków posłupowych trudno sprecyzować, odsłonięto je bowiem w różnych, odległych od siebie wykopach.

\section{Przeznaczenie pieców}

Z wnętrza pieców oraz ich sąsiedztwa pozyskano 1916 fragmentów dachówek gąsiorkowych typu mnich-mniszka ${ }^{4}$ - wklęsłych mniszek w kształcie połowy ściętego stożka i węższych od nich, wypukłych mnichów, przeznaczonych do nakrywania styków mniszek (Krajewski 1974, s. 216; Słownik terminologiczny 2004, s. 82).

\footnotetext{
${ }^{3}$ Por. http://www.mapywig.org/m/Polish_maps/series/126K_Mapa_Kwatermistrzostwa/ CP-24_Kol_IV_Sek_II.jpg, i http://www.mapywig.org/m/Polish_maps/series/126K_Mapa_ Kwatermistrzostwa/CP-16_Kol_III_Sek_II.jpg

${ }^{4}$ Ten rodzaj pokrycia dachowego nazywany były w XIX-wiecznej nomenklaturze budowlanej dachówkami francuskimi (Podczaszyński 1854, s. 71).
} 
Większość z nich (1693 szt.) znaleziono w warstwach eksplorowanych mechanicznie z całej powierzchni wykopów. Na ponad 1/4 fragmentów (564 egzemplarzach) widoczne były ślady przepalenia i zdeformowania, można zatem uznać je za destrukty powstałe w trakcie procesu wypalania. Tym samym założono, że opisywanych pieców używano do wypalania dachówek. Nie można jednak wykluczyć, że wypalano w nich również cegły, brak odpadów po ich produkcji nie wyklucza takiej możliwości. Przepalone i niekształtne cegły były bowiem używane do wypełniania wnętrz murów i fundamentów wznoszonych budynków. Na podstawie źródeł pisanych wiadomo, że możliwe było równoczesne wypalanie obu rodzajów wyrobów - cegieł i dachówek. Te ostatnie układano po zapełnieniu pieca cegłami, do $2 / 3$ jego wysokości. Znane były również urządzenia przeznaczone wyłącznie do wypalania dachówek (Hollestelle 1961, s. 31, 35-36; Arszyński 1970, s. 63, 65). Ponadto - jak wyżej wspomniano - mniejszy piec (nr II) pierwotnie funkcjonował jako urządzenie do wypalania kamieni wapiennych, o czym świadczą warstwy wapna zarówno w jego wnętrzu, jak i w rejonie otworu paleniskowego. W drugim etapie przebudowano go, dostosowując do wypalania ceramiki budowlanej.

Dachówki zachowały się fragmentarycznie, nie odnotowano żadnego całego egzemplarza. Znaleziska te podzielono na pięć kategorii wielkościowych - od bardzo małych (1-5 cm), przez małe (6-10 cm), średnie (11-15 cm), duże $(16-20 \mathrm{~cm})$ i bardzo duże $(21-30 \mathrm{~cm})$. Niestety, odnotowano niewiele fragmentów dużych (33 szt., 1,7\%) i bardzo dużych (4 szt., 0,2\%), najwięcej było małych (995 szt., około 52\%) oraz bardzo małych ułamków dachówek (696 szt. około 36\%), mniej zaś średnich (188 szt., około 10\%). Znaczne rozdrobnienie wyrobów może świadczy o intensywnym użytkowaniu tego obszaru, zarówno w czasie funkcjonowania zakładu produkcyjnego, jak i w późniejszym okresie. Wśród wszystkich fragmentów dachówek, ponad 1/4 (564 szt.), stanowiły fragmenty przepalone, często zdeformowane. Wśród nich najwięcej zaliczono do bardzo małych (143 szt.) i małych (65 szt.).

W wyniku analizy kształtu i elementów konstrukcyjnych dachówek - wrębu, zaczepu i zakończenia (przepony), zidentyfikowano minimalną ich liczbę - 97 egzemplarzy. Były to wyroby typu mnich-mniszka, jedyny rodzaj dachówek przeznaczonych do pokrycia dachów, składający się z dwóch części (dolnej mniszki i górnego mnicha). Dachówki te są długie, mają korytkowaty, zwężający się kształt (ryc. 12). Mniszka zaopatrzona jest w zaczep umożliwiający zahaczenie jej za drewniany element konstrukcyjny dachu, tzw. łatę i w dwa wręby (wpusty) do zaczepienia mnicha. Ten ostatni ma kształt stożkowaty i na węższym końcu posiada krawędź (przeponę) wpuszczaną we wręby mniszki. Dachówki mniszki układa się w rzędach, bezpośrednio na łatach, bocznymi krawędziami ku górze, z kilkucentymetrowym zakładem, mnichy natomiast w ten sposób, że zakrywają od góry linię styku dwóch sąsiadujących ze sobą mniszek. Każdy mnich spoczywa na zaczepach dwóch położonych obok siebie mniszek. Obie części łączone są zaprawą wapienną. 

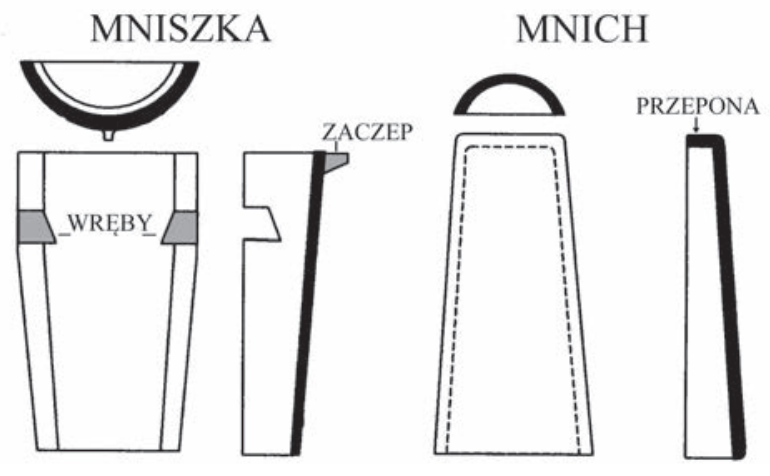

Ryc. 12. Elementy składowe dachówek gąsiorkowych zwanych mnich-mniszka (oprac. W. Bis)

Fig. 12. Components of ridge roof tiles called monk-nun (edited by W. Bis)

W tej grupie znalezisk przeważały mniszki (78 szt.), wśród nich zaś ułamki z zachowanym wrębem (60 szt.), znacznie mniej liczne były egzemplarze z zaczepem lub śladem po nim (18 szt.). Wymiary wrębów były zróżnicowane; ich głębokość dochodziła do 2,5 cm, szerokość nie przekraczała 4 cm. Jedynie 19 fragmentów dachówek pochodziło od mnichów. Ich cechą charakterystyczną były zakończenia (przepony), które w kilku przypadkach zachowały się w całości; ich szerokość wynosiła od 7,5 do $9 \mathrm{~cm}$. Na krawędziach niektórych dachówek widoczne były ślady odcinania przy pomocy drutu (ryc. 13-15).

Ponieważ na badanym terenie - jak wyżej wspomniano - nie odnaleziono całych dachówek, ich pełne wymiary można odtworzyć jedynie na podstawie analogii z innych stanowisk. Długość tych elementów wynosiła prawdopodobnie około $40 \mathrm{~cm}$, szerokość mogła być różna ${ }^{5}$. Największy fragment z opisywanego zbioru miał $28 \mathrm{~cm}$ długości. W kilku przypadkach możliwe było określenie zachowanej szerokości - od 9 do $17 \mathrm{~cm}$. W badanym zbiorze zidentyfikowano ułamki kilku gąsiorów, przeznaczonych do krycia krawędzi dachu (kalenicy), miały zachowaną szerokość równą 20 cm. Grubość wszystkich dachówek wahała się od 0,7 do 2,4 cm, wynosząc średnio $1,25 \mathrm{~cm}$.

Interesującymi znaleziskami były trzy gliniane haki - jeden cały a dwa zachowane częściowo (ryc. 16). Widniały na nich ślady przytwierdzania (przed wypaleniem) do glinianej powierzchni, najpewniej dachówki. Najprawdopodobniej były to elementy ozdobne gąsiorów, mocowane na ich szerszym końcu ${ }^{6}$.

${ }^{5}$ Na przykład nowożytne dachówki z zamku malborskiego miały szerokość od 15 do $18 \mathrm{~cm}$ (mniszki) lub od 7 do $10 \mathrm{~cm}$ (mnichy). Informacja ustna od pana Bernarda Jesionowskiego z Muzeum Zamkowego w Malborku.

${ }^{6}$ Nazwa takiej dachówki - gąsior, według Karola Podczaszyńskiego, wywodzi się od elementu, który miał często kształt wygiętej szyi zakończonej gęsią głową (Podczaszyński 1852, s. 71). Ozdobną funkcję pełniła również pionowa, drewniana ozdoba, umieszczana na kalenicy dachu, na skrajnych krokwiach, zwana pazdurem (Pevsner, Fleming, Honour 1992, s. 269). 

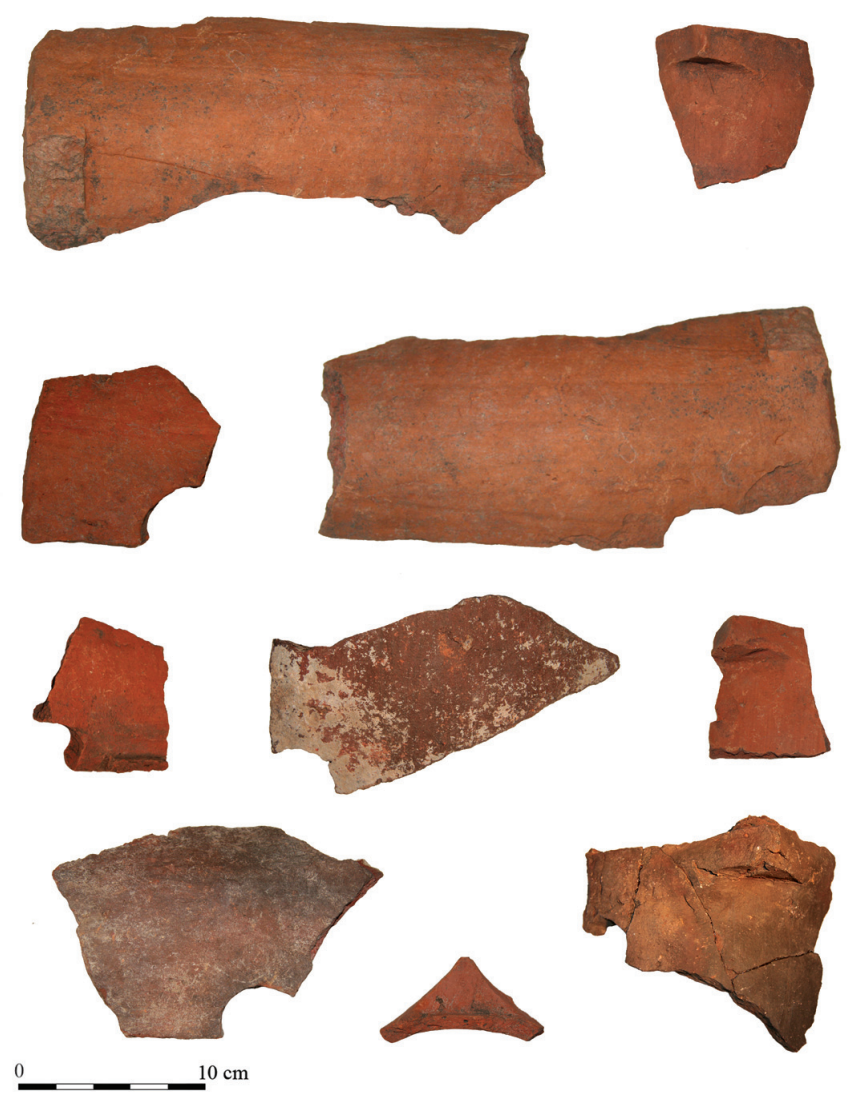

Ryc. 13. Płońsk, stanowisko 7, woj. mazowieckie. Fragmenty dachówek-mniszek (fot. W. Bis)

Fig. 13. Płońsk, site 7, Mazovian Voivodeship. Fragments of roof tiles-nuns (photo by W. Bis)

Proces przygotowywania gliny do produkcji dachówek, a także płytek posadzkowych wymagał staranniejszej obróbki niż materiału przeznaczonego do wytwarzania cegieł (Jars 1776, s. 11). W obu przypadkach był on wieloetapowy. Szczegółowe omówienie kolejnych czynności związanych z przygotowywaniem gliny do produkcji zaprezentowano na przykład w XIX-wiecznym poradniku nieznanego autora, tłumaczonym z języka niemieckiego, w którym zaprezentowano sposoby wyrabiania i wypalania cegieł oraz dachówek (Nauka wyrobu i wypalania 1847). Tematykę tę poruszano również we współczesnej literaturze przedmiotu (np. Wyrobisz 1961, s. 62-71; Arszyński 1970, s. 26-27; Horbacz 1996, s. 172-173). W pracach tych koncentrowano się na wyrobie cegieł i ich wypalaniu. Proces wytwarzania dachówek zaprezentował między innymi Marian Arszyński na przykładzie dachówek płaskich, tzw. karpiówek (Arszyński 1970, s. 56-58). Natomiast 

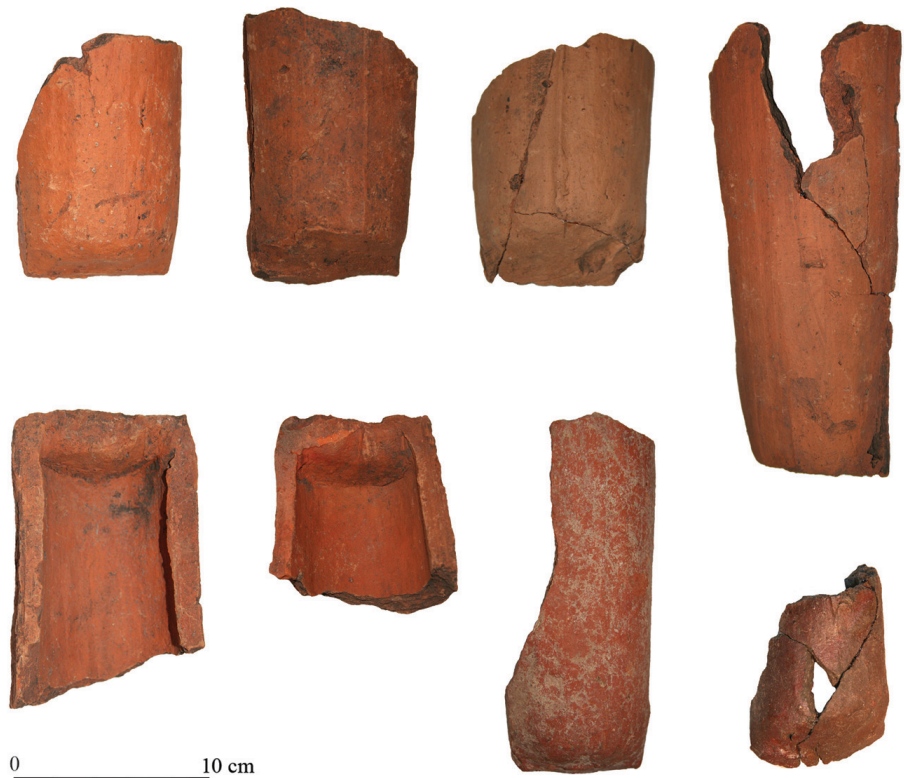

Ryc. 14. Płońsk, stanowisko 7, woj. mazowieckie. Fragmenty dachówek - mnichów (fot. W. Bis)

Fig. 14. Płońsk, site 7, Mazovian Voivodeship. Fragments of roof tiles - monks (photo by W. Bis)

sposoby produkcji dachówek holenderskich, zwanych esówkami, uwzględnił Gabriel Jars (1776, s. 10-13). Na podstawie przekazów pisanych oraz śladów zaobserwowanych na dachówkach karpiówkach przechowywanych w muzeach ustalono, że do ich wytwarzania konieczne było zastosowanie form. W dużych wytwórniach używano nawet kilku tysięcy odpowiednich deseczek (Arszyński 1970, s. 58). Formy stosowane przy produkcji różnych typów dachówek są widoczne na ilustracji z XVIII-wiecznego opracowania prezentującego sposób produkcji ceramiki budowlanej (ryc. 17) (Duhamel, Fourcroy, Gallon 1765, tab. I). Aby wykonać dachówki typu mnich-mniszka potrzebne były zapewne formy różnych kształtów i rozmiarów, właściwe dla każdego z elementów. Przygotowany wcześniej rozwałkowany kawałek gliny, odpowiadający wielkości dachówki, układano bezpośrednio na odpowiedniej formie, ręcznie modelowano i odcinano nadmiar gliny, profilując krawędzie. W przypadku mnichów dodatkowo wykonywano przeponę. Do zrobienia dachówki mniszki konieczne było uformowanie zaczepu i wycięcie wrębów niezbędnych do zamocowania mnicha. Masa ceramiczna do produkcji tego typu dachówek musiała mieć taką gęstość i plastyczność, aby po zdjęciu z formy i odłożeniu do wyschnięcia wyrób nie uległ deformacji.

Część analizowanych fragmentów mnichów miała chropowate powierzchnie wewnętrzne, a także ślady piaszczystej podsypki, która ułatwiała zdjęcie 

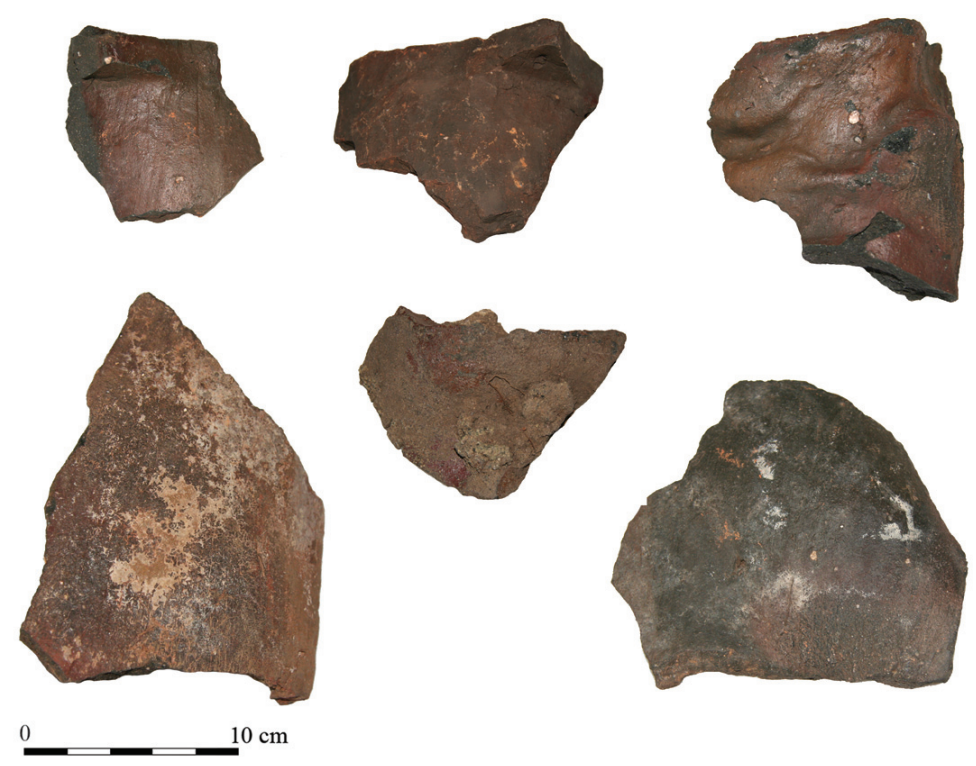

Ryc. 15. Płońsk, stanowisko 7, woj. mazowieckie. Ułamki przepalonych i zdeformowanych dachówek gąsiorkowych (fot. W. Bis)

Fig. 15. Płońsk, site 7, Mazovian Voivodeship. Fragments of over-fired and deformed ridge roof tiles (photo by W. Bis)

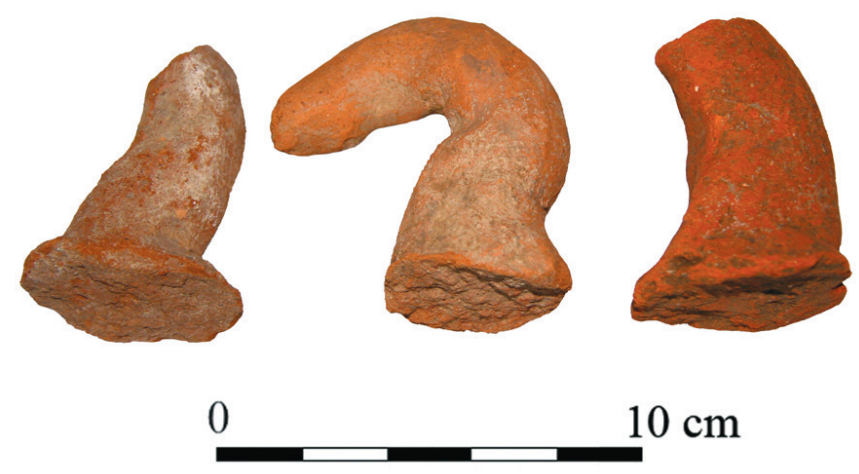

Ryc. 16. Płońsk, stanowisko 7, woj. mazowieckie. Ozdobne elementy gąsiorów (fot. W. Bis)

Fig. 16. Płońsk, site 7, Mazovian Voivodeship. Ornamental elements of ridge roof tiles (photo by W. Bis) 


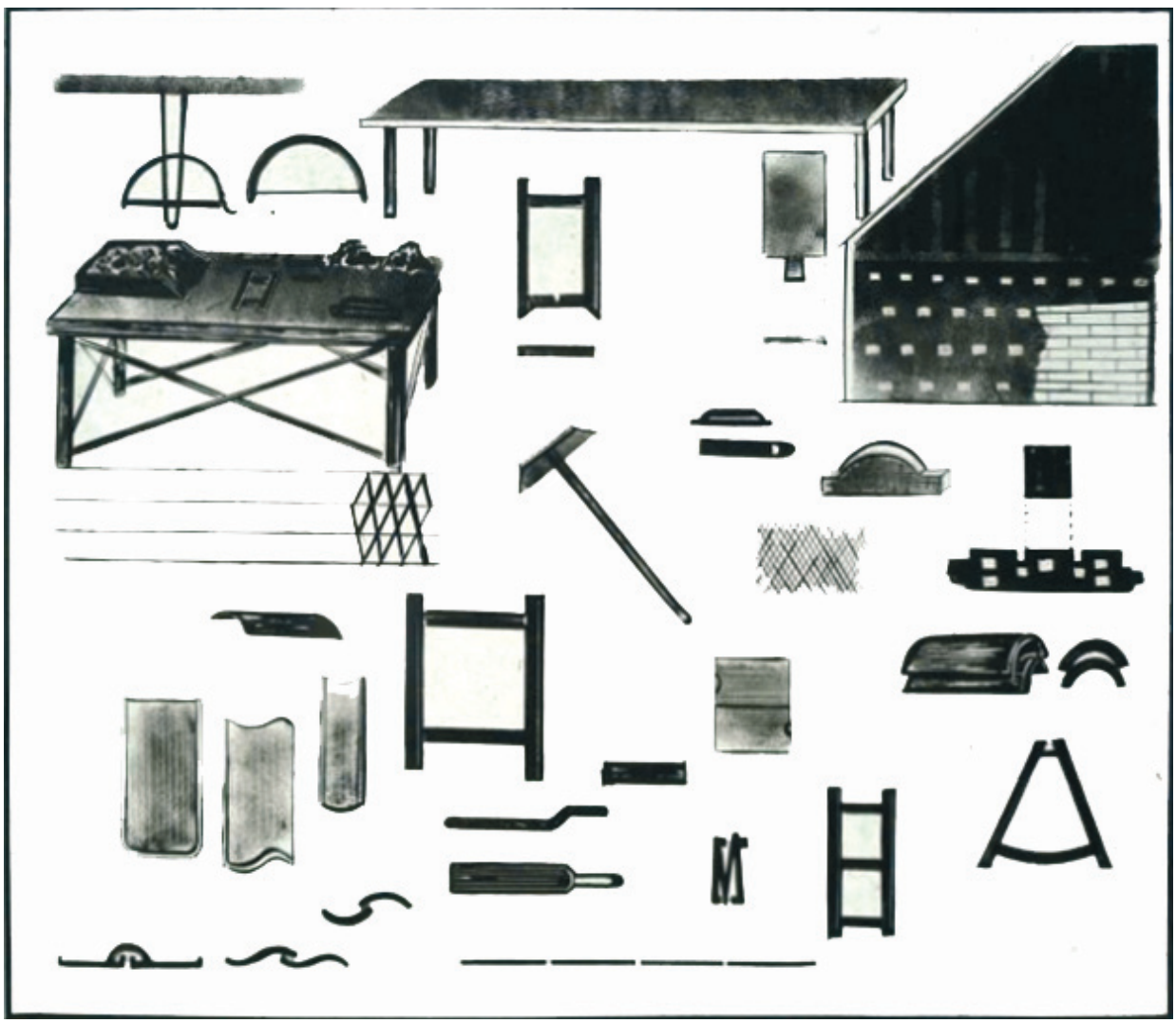

Ryc. 17. Narzędzia do produkcji dachówek używane w XVIII-wiecznej wytwórni (wg Duhamel, Fourcroy, Gallon 1765)

Fig. 17. Roof tiles manufacturing tools used in the $18^{\text {th }}$ century plant (after Duhamel, Fourcroy, Gallon 1765)

wykonanego wyrobu z formy. Wśród nich odnotowano nieliczne ułamki ze śladami wygładzania obu powierzchni. Wszystkie mniszki miały wygładzoną powierzchnię. O dobrej jakości gliny i starannym przygotowaniu masy ceramicznej do produkcji analizowanych dachówek świadczyć mogą bardzo rzadko widoczne margle.

W toku prac archeologicznych na opisywanym obszarze pozyskano także cegły, zarówno całe egzemplarze, jak i różnej wielkości fragmenty. Na wszystkich widniały ślady ręcznego formowania, tj. charakterystyczne rowki wykonane palcami przez strycharzy, pozostawione na jednej z powierzchni podczas zbierania nadmiaru gliny wciśniętej do formy. W kilku przypadkach zaobserwowano ślady bezpośredniego i długotrwałego działania ognia - okopcenia, spieczenia powierzchni bądź zdeformowania. Wszystkie całe cegły pochodziły z elementów konstrukcyjnych pieców, stanowiących obudowę palenisk lub z ław. Znaczną liczbę 
ułamków cegieł (130 szt.), tworzących gruz ceglany, znaleziono w warstwach eksplorowanych mechanicznie lub w wypełniskach obiektów. Mogły być one elementami glinianego sklepienia wykonywanego po załadowaniu surówki do pieca, w celu uszczelnienia urządzenia przed rozpoczęciem wypalania wsadu.

\section{Datowanie pieców}

Na podstawie wstępnego datowania naczyń ceramicznych ${ }^{7}$, kilkunastu fragmentów kafli garnkowych i miskowych oraz analizy rozmiarów cegieł zastosowanych do budowy pieców, a także znalezionej w rejonie pieca monety, wstępnie można przyjąć, że początek funkcjonowania pieców przypadał na koniec XV lub początek XVI wieku, a kres działania wytwórni - na początek XVII stulecia. Pośrednich wskazówek na ten temat mogą dostarczyć także dane ze źródeł pisanych, informujące o funkcjonowaniu w Płońsku murowanych budynków.

Przy ustalaniu czasu funkcjonowania opisywanych urządzeń pomocna była analiza wymiarów cegieł użytych do ich budowy i porównanie z wymiarami cegieł pochodzącymi z innych murowanych obiektów z terenu Mazowsza, datowanych na XV i XVI wiek. Wielkość cegieł zastosowana do wzniesienia pieców najczęściej wynosiła 260-270 mm długości, 120-133 mm szerokości i 75-83 mm grubości. Z badań przeprowadzonych przez Władysława Borusiewicza wynika, że w XVI stuleciu w murowanych budynkach na Mazowszu używano cegieł o rozmiarach mieszczących się w przedziałach: 255-280×125-140×67-82 mm (Borusiewicz 1985, s. 59). Takie same wielkości zaobserwował Zdzisław Tomaszewski, badając mury XVI-wiecznych budynków na Starym Mieście w Warszawie (Tomaszewski 1955, s. 47). Cegły datowane na połowę XVI stulecia, pochodzące z murów zamku w Czersku, wzniesionych w tym czasie, również mają podobne wymiary i wynoszą odpowiednio: 270-284×133-140×77-82 mm (Zagrodzki 1996, s. 43-44, przypisy 110, 111, 113). Ponadto w XVI-wiecznych murach kościoła pw. św. Katarzyny na warszawskim Służewie stwierdzono użycie cegieł o wymiarach: 260-270×120-140×75-85 mm . Budulec o podobnej wielkości zastosowano też w zamku królewskim w Tykocinie, znajdującym się na pograniczu Mazowsza i Podlasia. Do budowy tamtejszych murów, datowanych na 2. połowę XVI wieku, użyto cegieł o wymiarach: 279-284×130-133×76-78 mm (Bis, Bis 2015, s. 323).

\footnotetext{
${ }^{7}$ Na podstawie cech morfologicznych i technologicznych późnośredniowieczne i nowożytne naczynia ceramiczne można datować na XV-XVII wiek. Pełna analiza tych materiałów, przygotowana przez Tadeusza Morysińskiego, stanowić będzie osobny rozdział monograficznego opracowania stanowiska.

${ }_{8}$ Pomiary uzyskane przeze autora niniejszego artykułu w trakcie badań archeologiczno-architektonicznych kościoła, prowadzonych w latach 1996-2001 pod kierunkiem dr Marii Dąbrowskiej z Instytutu Archeologii i Etnologii PAN w Warszawie.
} 
Nieliczne i mocno rozdrobnione fragmenty kafli garnkowych i miskowych mogą być datowane jedynie w przybliżeniu. Na podstawie zachowanych krawędzi stwierdzono, że kafle miały otwory w kształcie czterolistnej koniczyny i kwadratowe. Te pierwsze mogą pochodzić z okresu od początku XV wieku po lata 60. XVI wieku, drugie najczęściej występowały od 1. połowy XVI wieku (Dąbrowska 1987, s. 84-85, 88).

Prawdopodobnie z końcowego okresu funkcjonowania wytwórni pochodziła moneta - trojak Zygmunta III Wazy, znaleziona po zachodniej stronie pieców, w odległości około $20 \mathrm{~m}$ od nich. Na awersie widnieje popiersie króla w koronie oraz napis otokowy: $\mathrm{SIG} \cdot \mathrm{III} \bullet \mathrm{D} \cdot \mathrm{G} \cdot \mathrm{REX} \cdot \mathrm{POL} \cdot \mathrm{MDL} \bullet$, na rewersie zaś liczba III, pod nią herby Polski, Wazów i Litwy, pod nimi rok 1621. Poniżej, w trzech wersach znajduje się napis: GROS•ARGE TRIP•REGN POLONI oraz u dołu herb Sasów (Kamiński, Kurpiewski 1990, s. 250, poz. 1370).

Kto mógł być odbiorcą wyrobów? Położenie wytwórni w niewielkiej odległości od Płońska pozwala sadzić, że jej produkcja nastawiona była na miejscowych bądź okolicznych odbiorców. Z XVI-wiecznego opisu ziem polskich Aleksandra Gwagnina wynika, że zabudowa Płońska była w tym czasie drewniana (Gwagnin 1860, s. 21). Jeszcze pod koniec XVIII wieku źródła pisane informują, że na 178 domów stojących w mieście tylko klasztor, kościół i jeden budynek żydowski w rynku były murowane (Barbasiewicz 1984, s. 47, przypis 46). Z kolei wiadomo, że już na początku XVI stulecia przy farze istniał szpital dla biednych, który w roku 1817 opisywany jest jako murowany i kryty dachówką holenderską. W XVIII stuleciu na rynku miejskim znajdował się ratusz, który jeszcze na początku XIX wieku był drewniany, piętrowy i kryty dachówką (Barbasiewicz 1984, s. 54). Nie można wykluczyć, że dachówki stosowano do krycia dachów tutejszych budynków drewnianych również wcześniej, choćby plebanii i domu wikariuszy, znajdujących się w sąsiedztwie fary (MRPS 1908, s. 36, nr 552), a także domów mieszczańskich.

W XVI i XVII wieku najważniejszymi budynkami Płońska były kościoły. O funkcjonowaniu fary już na początku XV wieku dowiadujemy się z notatki sądowej z 1413 roku, informującej, że w okolicy świątyni odprawiano sądy (Handelsman 1920, nr 2124; Karp 1983, s. 32). Kolejny raz farę wzmiankowano w 1446 roku (Stownik historyczno-geograficzny 1998, s. 238). W 1565 roku opisywano ją jako budynek „,wielki murowany” i zlokalizowany w pobliżu rynku (KZSP 1979, s. 56). W czasie wojen szwedzkich z połowy XVII i początku XVIII wieku, świątynia uległa uszkodzeniu. Na podstawie wizytacji z 1775 roku wiadomo, że jego mury wymagały naprawy, a na ten cel sprowadzono „sześć tysięcy cegły i trzydzieści korcy płońskiej miary wapna” (Grzybowski 1989, s. 59). Odnotowano również, że połacie dachu miały mieszane pokrycie, zastosowano zarówno gont, jak i dachówkę (Grzybowski 1989, s. 59). W 1781 roku kościół uległ spaleniu (Kunkel 2006, s. 295), co w konsekwencji doprowadziło do jego likwidacji, zaś na początku XIX wieku zniszczone mury rozebrano do fundamentów (Stownik geograficzny 1887, s. 313; Stronczyński 2013, s. 127). 
Drugą świątynią w Płońsku o późnośredniowiecznej metryce był klasztor Karmelitów, ufundowany w 1418 roku przez księżną Aleksandrę i jej męża Siemowita IV (Żebrowski 1994, s. 343). W 1462 roku księżna mazowiecka Katarzyna poszerzyła uposażenie zakonu, nadając mu półtorej włóki ziemi (Żebrowski 1994, s. 344). Jej przypisuje się również fundację kościoła konwentualnego pw. Najświętszej Marii Panny (Slownik historyczno-geograficzny 1998, s. 238). Prawdopodobnie w 1540 roku, ze środków królowej Bony Sforzy, wzniesiono murowaną świątynię istniejącą w obecnej bryle, zachowując większość cech stylu gotyckiego (KZSP 1979, s. 56; Galicka 1987, s. 145 i przypis 8; Kunkel 2006, s. 295). Zbudowano ją na miejscu zajętym pierwotnie przez zapewne drewniane budynki klasztorne (Barbasiewicz 1984, s. 55). Ten murowany kościół został zniszczony w czasie wojen szwedzkich, lecz potem go odbudowano. W końcu XVIII wieku, po spaleniu fary, w kościele klasztornym odprawiano nabożeństwa, stał się wówczas kościołem parafialnym, przejmując także wezwanie św. Michała Archanioła (Kunkel 2006, s. 295). Karmelici prowadzili w nim duszpasterstwo do kasaty zakonu w 1865 roku (Diecezja Płocka 1978, s. 283).

Największy rozwój gospodarczy Płońska przypadał na XV i XVI wiek. Sprzyjało temu położenie miasta przy ważnych drogach handlowych; znajdował się tu węzeł komunikacyjny regionu, szlaki prowadzące do Raciąża i Płocka, do Ciechanowa, w stronę Mławy i Nowego Miasta, a także Zakroczymia i Wyszogrodu. Najważniejszy był jednak ,gościniec wielki”, wiodący z centralnego Mazowsza przez Ciechanów w kierunku Prus (Barbasiewicz 1984, s. 44). Już od XV stulecia funkcjonowały także dwa płońskie przedmieścia - na północ i na południe od miasta lokacyjnego (Barbasiewicz 1984, s. 37). W XVI stuleciu odbywały się tam wówczas cotygodniowe targi, trzy doroczne jarmarki i działali liczni rzemieślnicy (Barbasiewicz 1984, s. 44-45). W tym czasie miały też miejsce największe inwestycje związane z budową kościołów - parafialnego i konwentualnego. Stopniowy upadek gospodarczy miasta następował od lat 70. XVI wieku, pogłębiony jeszcze przez zniszczenia w czasie potopu, w 2. połowie XVII wieku. Stan ten utrzymywał się do 2. połowy XVIII stulecia. Dopiero wówczas nastąpił napływ nowych mieszkańców, powstały nowe zakłady produkcyjne i budynki mieszkalne (Barbasiewicz 1984, s. 43).

Grunty, na których odkryto pozostałości pieców produkcyjnych, znajdują się na pograniczu miasta lokacyjnego oraz ziem należących niegdyś do sąsiadującego z Płońskiem majątku w Poświętnem. Źródła pisane informują, że folwark ten (Poswyanthne) już od 1495 roku był własnością plebana płońskiego i stanowił uposażenie tejże parafii (Lustracje 1965, s. 197; Stownik historyczno-geograficzny 1998, s. 243). Nie jest znany przebieg granicy między tymi własnościami. Folwark znajdował się na północ od rzeki Płonki, piece odsłonięto natomiast na jej południowym brzegu. Nie wiadomo jednak, czy ten ciek stanowił naturalną granicę. 
Na podstawie przytoczonych powyżej danych można przyjać, że opisywany warsztat działał na potrzeby podjętych w połowie XVI wieku inwestycji kościelnych, związanych z budową lub modernizacją kościołów parafialnego i klasztornego. Ustalenie zasięgu własności miejskiej i parafialnej umożliwiłoby sprecyzowanie odbiorcy produktów wytwórni. Działając na gruntach folwarku Poświętne produkowałby zapewne na potrzeby kościoła parafialnego, natomiast na terenie miejskim - na rzecz fundowanego przez królową Bonę Kościoła Konwentualnego Karmelitów. W dużych ośrodkach miejskich wytwórnie produkujące ceramiczny materiał budowlany na potrzeby konkretnej inwestycji nadal funkcjonowały po ukończeniu budowy. Stawały się dochodowymi zakładami produkującymi na zbyt i przynoszącymi dochody ich właścicielom (Mączyński 2010, s. 202-203).

\section{Piece z Płońska na tle porównawczym}

Problematykę związaną z wytwórczością ceramiki budowlanej w polskiej literaturze przedmiotu podejmowano kilkakrotnie, bazując głównie na źródłach pisanych (Arszyński 1970; Bogucka 1961, s. 125-140; Wyrobisz 1961, s. 55-82; 1963; 1972, s. 62-70; Kąsinowski 1970, s. 52-56; Świętochowski 1971, s. 203-229; Rutkowska-Płachcińska 1978, s. 150-179). Zajmowano się głównie organizacją cegielni, procesem produkcyjnym, przeważnie odtwarzając wytwarzanie cegieł, a także kosztami produkcji. Informacje o ceramice budowlanej pozyskiwanej w efekcie badań archeologicznych w rodzimych publikacjach archeologicznych były wcześniej rzadko prezentowane, choć w ciągu ostatniej dekady można zaobserwować zmianę tej tendencji (np. Kaczmarek 1995; Małachowicz 2005; Pietras 2005; Dąbal, Szczepanowska 2015 - tam dalsza literatura; Bis, Bis 2015). Niezwykle mało było - jak dotąd - informacji o znaleziskach pieców do wypalania ceramiki budowlanej na terenie obecnych ziem polskich. Być może część takich reliktów nie została dobrze zinterpretowana lub opublikowana. Tylko nielicznym urządzeniom poświęcono odrębne publikacje. Dwa z nich miały konstrukcję zbliżoną do pieców odkrytych w Płońsku - zaopatrzone były w dwa paleniska i ławy do układania surówki, były też podobnie obsługiwane. Jeden z nich, najczęściej przywoływany w literaturze przedmiotu, to piec odsłonięty na początku XX wieku w Narzymiu pod Działdowem (Arszyński 1970, s. 62-68; Rutkowska-Płachcińska 1978, s. 163). Stan zachowania pieca umożliwił jego rekonstrukcję, określenie sposobu obsługi i prześledzenie procesu działania.

Drugi obiekt odkryto w 1997 roku w południowo-wschodniej Polsce - w Chełmie-Bieławinie. Był to częściowo zachowany piec ceglarski. Kwadratowy w planie zarys urządzenia nie był kompletny; jego szerokość wynosiła 5,5 m, natomiast z powodu zniszczenia obiektu nie można było określić jego pierwotniej długości (ryc. 18). Fundamenty wykonano z kamieni i cegieł łączonych gliną. Piec miał 


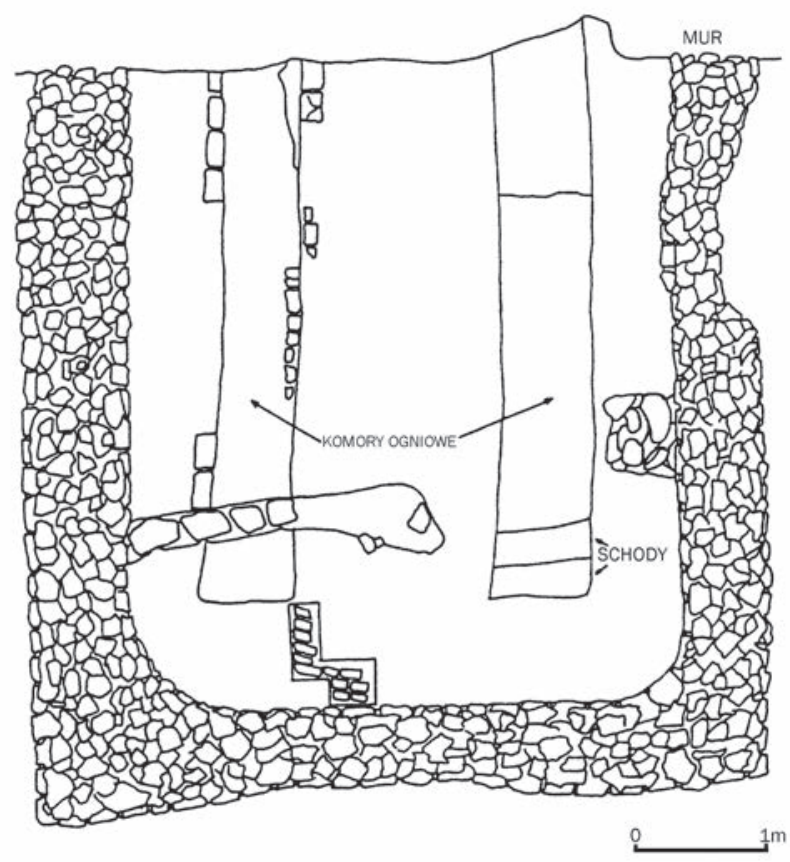

Ryc. 18. Chełm-Bieławin. Rzut poziomy pieca do wypalania ceramiki budowlanej z XVI/ XVII wieku (wg Gołub 1997)

Fig. 18. Chełm-Bieławin. Plan of kiln for firing construction ceramics from the $16^{\text {th }} / 17^{\text {th }}$ century (after Gołub 1997)

dwie komory paleniskowe wyłożone cegłami palcówkami. Na podstawie pozyskanych znalezisk autor badań określił przypuszczalny czas jego funkcjonowania na XVI/XVII wiek (Golub 1997, s. 163-164). Z terenu ziem polskich znane są również inne piece do wypalania ceramiki budowlanej, jednak sposób ich budowy i obsługi był inny. Urządzenia te są mniejsze, mające jedną komorę paleniskową i ceglany ruszt (łęki). Najwcześniej datowane - na XIII wiek - odkryto na terenie ponorbertańskiego klasztoru w Strzelnie (Chudziak 1998, s. 163-165), klasztoru Dominikanów w Krakowie (Bojęś-Białasik, Niemiec 2013, s. 313) i klasztoru Cystersów w Lubiążu (Łużyniecka 2002, s. 225-227). Zapewne późnośredniowieczny piec funkcjonował na terenie klasztoru Kanoników Regularnych w Trzemesznie (Wiewióra 2000, s. 261-262), zaś obiekt datowany na przełom XV i XVI wieku odkryto w Suchyni w okolicy Kraśnika ${ }^{9}$ (ryc. 19). W przypadku niektórych urządzeń dysponujemy niewielką liczbą informacji odnośnie ich konstrukcji i przeznaczenia.

\footnotetext{
${ }^{9}$ Za udostępnienie informacji i materiałów dziękuję panu Zbigniewowi Wichrowskiemu, kierownikowi prac archeologicznych.
} 


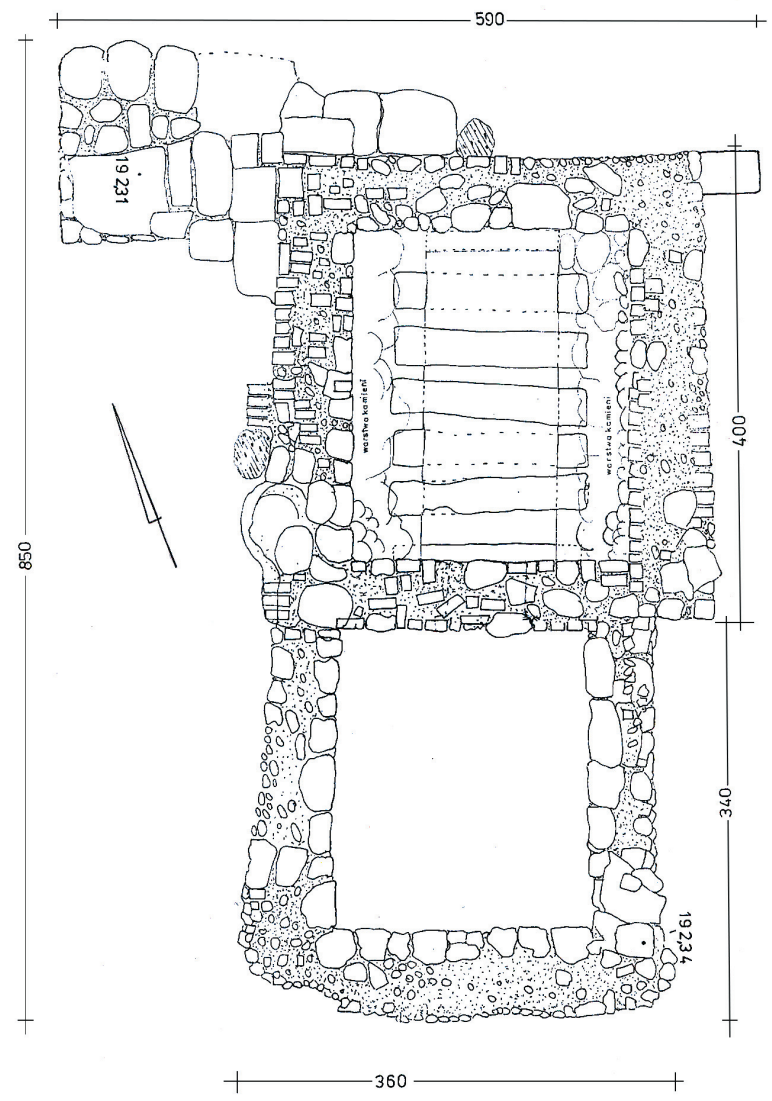

Ryc. 19. Suchynia koło Kraśnika. Rzut poziomy pieca do wypalania ceramiki budowlanej(?) z przełom XV i XVI wieku (rys. Z. Wichrowski)

Fig. 19. Suchynia near Kraśnik. Plan of kiln for firing construction ceramics(?) from the turn of the $15^{\text {th }}$ and $16^{\text {th }}$ centuries (drawing by Z. Wichrowski)

Znacznie liczniej reprezentowane są tego rodzaju urządzenia na terenie Czech, Słowacji, Węgier i Niemiec. Katalog pieców znanych z publikacji, odkrytych w zachodniej i środkowej Europie, opracował Marian Čurný (2012 - tam dalsza literatura). Nowożytne piece do wypalania ceramiki budowlanej znane są również z Litwy, na przykład z Wilna (Poška 2009, s. 466-467) i Trok (Sarcevičius 2009, s. 468-469). Urządzenia, w których wypalano zarówno cegły, jak i dachówki, pochodzą na przykład z miejscowości Milevsko w Czechach; ten zespół obiektów datowano na XIII wiek. Jeden z pieców wykorzystywany był również do wypalania kamieni wapiennych (Drda 1983, s. 167-173). Piec do produkcji dachówek i płytek posadzkowych z XIII wieku odkryto na przykład w miejscowości North-Grange na terenie Wielkiej Brytanii (Eames 1961, s. 137-168). Urządzenie przeznaczone 
także do wypalania dachówek (część wsadu znaleziono in situ, ułożone na ruszcie nad komorami paleniskowymi) znaleziono w miejscowości Öhringen-Michelbach na terenie Niemiec; funkcjonowało ono pod koniec XV lub w XVI stuleciu (Schäfer 1983, s. 225-229). Z miejscowości Haldensleben w Saksonii-Anhalt pochodzi natomiast piec łączący dwie funkcje - wypalanie cegieł i kamieni wapiennych, datowany od XIII do XV wieku (Tonezzer 2002, s. 106-107). Takie praktyki potwierdzają informacje ze źródeł pisanych (Arszyński 1970, s. 71), choć znane są również piece - wapienniki przeznaczone tylko do prażenia kamieni wapiennych (np. Łużyniecka 2002, s. 225-227).

\section{Podsumowanie}

Piece odsłonięte w okolicy Płońska są jednymi z niewielu tego rodzaju obiektów, znanych dotychczas z terenu Polski. Stanowią cenne źródło do badań nad budownictwem, dawną wytwórczościąi kulturą materialną u schyłku średniowiecza oraz na początku czasów nowożytnych. Na podstawie danych archiwalnych można sądzić, że piece te mogły działać w okresie prosperity miasta w końcu XV i 1. połowie XVI wieku, a produkowały materiał budowlany na potrzeby miejscowej parafii lub klasztoru Karmelitów.

\section{Literatura}

Arszyński M.

1970 Technika i organizacja budownictwa ceglanego w Prusach w końcu XIV i w pierwszej polowie XV wieku, [w:] Studia i materialy z historii kultury materialnej, t. 39, Studia z dziejów rzemiosła i przemysłu, t. 9, red. Z. Kamieńska, Wrocław, s. 7-139.

Barbasiewicz M.

1984 Studium historyczno-urbanistyczne Płońska, Studia i Materiały Pracowni Konserwacji Zabytków, Warszawa.

Bartoszewicz H.

2003 Źródła kartograficzne do historii miast Mazowsza Pótnocnego w drugiej połowie XVIII i pierwszej połowie XIX wieku, Rocznik Mazowiecki, t. 15, s. $169-179$.

Bednarczyk J., Sujecka A., Janicki K.

2008 Sprawozdanie z archeologicznych badań ratowniczych w Płońsku, stan. 7, gm. Płońsk, woj. mazowieckie, maszynopis z archiwum WKZ Delegatura w Ciechanowie, Poznań. 
Bis M., Bis. W.

2015 Inne wyroby z gliny i zabytki różne, [w:] Tykocin - zamek nad Narwia (XV-XVIII w.). Badania archeologiczne w latach 1961-1963 i 1999-2007, red. M. Bis, W. Bis, Warszawa, s. 321-328.

Bogucka M.

1961 Cegielnia gdańska w XVI w., [w:] Studia i materiały z historii kultury materialnej, t. 10, Studia z dziejów rzemiosła i przemysłu, t. 1, red. Z. Kamieńska, Wrocław, s. 125-140.

Bojęś-Białasik A., Niemiec D.

2013 Kościót i klasztor Dominikanów w Krakowie w świetle badań archeologiczno-architektonicznych w latach 2010-2012, [w:] Sztuka w kręgu krakowskich dominikanów, red. A. Markiewicz, M. Szyman, M. Walczak, Kraków, s. 257-313.

Borusiewicz W.

1985 Budownictwo murowane w Polsce, Warszawa-Kraków.

Buzás M.

1995 Téglapítkezés gyarkorlata a Nyugát-Dunántúlon, [w:] Nyugat-Dunántúl népi

Chudziak W.

épitészete, red. M. Cseri, Szentendre-Szombathely, s. 451-461.

1984 Najstarsza „cegielnia” ze Strzelna, Z otchłani wieków, t. 50, z. 3-4, s. 163165.

Čurný M.

2012 Tehliarskie pece. Náčrt ploblematyky v stredoveku a novoveku v stradnej a západnej Európe, [w:] Archeologia Technica. Zkoumání výrobních obiektio a technologií archeologickými metodami, t. 23, red. J. Merta, Brno, s. 71-82.

Dąbal J., Szczepanowska K.

2015 Budując Twierdzę Wisłoujście. Charakterystyka detali architektonicznych, ceramiki budowlanej i zapraw, [w:] Gdańsk. Twierdza Wisłoujście. Badania archeologiczno-architektoniczne w latach 2013-2014, red. J. Dąbal, K. Krawczyk, T. Widerski, Gdańsk, s. 157-178.

Dąbrowska M.

1987 Kafle i piece kaflowe w Polsce do końca XVIII wieku, [w:] Studia i materiały z historii kultury materialnej, t. 58, red. Z. Kamieńska, Wrocław.

Diecezja Płocka

1978 Diecezja Płocka: struktura personalno-administracyjna (stan z dnia 1 października 1977 r.), red. W. Lis, Płock.

Drda M.

1983 Cihelna 13. století v Milevsku, Archaeologia historica, t. 8, s. 167-173.

Duhamel H., Fourcroy C., Gallon J.

1765 Die Kunst Mauer- und Dachziegel zu streichen, [w:] Schauplatz der Künste und Handwerke, oder vollständige Beschreibung derselben, t. 4, Leipzig - Mietau - Königsberg, s. 155-224.

Eames E. S.

1961 A trirthieenth-ceuntry tile kiln site at North Geange, Meaux, Bewverley, Yorkshire, Medieval Archaeology, t. 5, s. 137-168. 
Galicka I.

1987 Z problemów gotyckiej architektury sakralnej na Mazowszu, Biuletyn Historii Sztuki, t. 49, z. 1-2, s. 145-164.

Gołub S.

1997 Badania i częściowa rekonstrukcja średniowiecznej kamiennej wieży (stan. 1/2) i pozostałości cegielni (stan. 145) w Chetmie-Bieławinie, Archeologia Polski Środkowowschodniej, t. 2, s. 162-164.

Grzybowski M. M.

1989 Materiały do dziejów ziemi płockiej, t. 5: Ziemia płońska, Płock.

Gwagnin A.

1860 Z kroniki Sarmacyi europejskiej. Opisanie Polski, Wielkiego Księstwa Litewskiego, Ziemie Pruskiej, Ziemie Inflanckiej, Ziemie Żmudzkiej, wyd. K. J. Turowski, Kraków.

Handelsman M.

1920 Księga ziemska płońska 1400-1417, [w:] Najdawniejsze księgi sqdowe mazowieckie, t. 1, wyd. M. Handelsman, Warszawa.

Hollestelle J.

1961 De Steenbakkerij In de Nederlanden tot omstreeks 1560, Arnhem.

Horbacz T. J.

1996 Teoria a doświadczenie. Wokót kwestii zwiqzanych z produkcja cegły w średniowieczu, Archaeologia Historica Polona, t. 3, s. 167-181.

Jakab A.

2005 A téglavetésről, Jósa András Múzeum Évkonyve, t. 47, s. 345-365.

Jars G.

1776 Sposób wyrabiania czyli strychowania cegiel jako y dachówek sposobem w Holanydi używanym, wypalając one torfem, czyli darniq suszona, tłum. H. Małachowski, Warszawa.

Kaczmarek J.

1995 Ceramika budowlana ze stanowiska nr 3 w Łeknie, [w:] Studia i materialy do dziejów Pałuk, t. 2: Osadnictwo i architektura w rejonie Łekna we wczesnym średniowieczu, red. A. Wyrwa, Poznań, s. 229-248.

Kamiński C., Kurpiewski J.

1990 Katalog monet polskich 1587-1632, Warszawa.

Karp M.

1983 Szkice z średniowiecznych dziejów Płońska, [w:] Dzieje miasta Płońska, red. A. Kociszewski, Ciechanów, s. 24-29.

KZSP

1979 Katalog Zabytków Sztuki w Polsce, t. 10, Dawne województwo warszawskie, Kąsinowski A.

z. 16, Płońsk i okolice, red. I. Galicka, H. Sygietyńska, Warszawa.

1970 Podstawowe zasady murarstwa gotyckiego na Pomorzu Zachodnim, Studia z dziejów rzemiosła i przemysłu, t. 10, Wrocław, s. 47-131.

Krajewski K.

1974 Mała encyklopedia architektury i wnętrz, Wrocław. 
Kunkel R. M.

2006 Architektura gotycka na Mazowszu, Warszawa.

Lustracje

1965 Lustracje województwa płockiego 1565-1789, red. A. Sucheni-Grabowska, S. M. Szacherska, Warszawa.

Łużyniecka E.

2002 Architektura klasztorów cysterskich. Filie lubiaskie i inne cenobia ślqskie, Wrocław.

Małachowicz M.

2005 Ceramika budowlana średniowiecznego Wrocławia, [w:] Wschodnia strefa Starego Miasta we Wrocławiu w XII-XIV wieku. Badania na Placu Nowy Targ, red. C. Buśko, Wrocław, s. 111-134.

Mączyński R.

2010 Zespoly architektoniczne Collegium Regium i Collegium Nobilium warszawskich pijarów 1642-1834, Warszawa.

MRPS

1908 Matricularum Regni Poloniae Summaria, cz. 3, wyd. T. Wierzbowski, Warszawa.

Nauka wyrobu i wypalania

$1847 \quad$ Nauka wyrobu i wypalania dobrych cegiet i dachówek, jako też zakładania cegielni: zebrana z praktycznych przekonań, dla właścicieli cegielni, strycharzy i budowniczych: z abrysem na stawianie cegielni i szopy, Bochnia.

Pevsner N., Fleming J., Honour H.

1992 Encyklopedia architektury, Warszawa.

Pietras M.

2005 Gotycka cegła konstrukcyjna ze stanowiska Ostrów Tumski 9/10, [w:] Poznań we wczesnym średniowieczu, t. 5, red. Hóčka-Krenz, Poznań, s. 170-177.

Podczaszyński K.

$1854 \quad$ Nomenklatura architektoniczna czyli słowomiennik cieśliczych polskich wyrazów, Warszawa.

Poška T.

2009 Krosnis Rinktinès g. 6, Vilniuje, Archeologiniai tyrinëjimai Lietuvoje 2008 metais, s. 466-467.

Rutkowska-Płachcińska A.

1978 Budownictwo, [w:] Historia kultury materialnej Polski w zarysie, t. 2:

Od XIII do XV wieku, red. A. Rutkowska-Płachcińska, Wrocław, s. 150-179.

Sarcevičius S.

2009 Tyrimai Galvès g. 4, Trakuose, Archeologiniai tyrinèjimai Lietuvoje 2008 metais, s. 468-469.

Schäfer H.

1983 Zwei Ziegelöfen in Öhringen-Michelbach, Hohenlohekreis, Archäologische Ausgrabungen in Baden-Württemberg 1982, Stuttgart, s. 225-229. 
Stownik geograficzny

1887 Słownik geograficzny Królestwa Polskiego i innych krajów słowiańskich, t. 8, wyd. B. Chlebowski, Warszawa.

Stownik historyczno-geograficzny

1998 Słownik historyczno-geograficzny województwa płockiego w średniowieczu, z. 3: Ml-Św., red. A. Borkiwicz-Celińska, Warszawa.

Stownik terminologiczny

2004 Słownik terminologiczny sztuk pięknych, red. K. Kubalska-Szulkiewicz, Warszawa.

Smuda H.

1983 Środowisko geograficzne Płońska i okolic, [w:] Dzieje miasta Płońska, red. A. Kociszewski, Ciechanów, s. 7-14.

Stronczyński K.

2013 Kazimierza Stronczyńskiego opisy i widoki zabytków w Królestwie Polskim (1844-1855), t. 4: Gubernia Płocka, oprac. R. Kunkel, przy udziale W. Szymańskiego, Warszawa.

Świętochowski R.

1971 Cegielnie oo. Dominikanów w Warszawie (1640-1784), Kwartalnik Historii Kultury Materialnej, R. 19, nr 2, s. 203-229.

Tomaszewski Z.

1955 Badanie cegły jako metoda pomocnicza przy datowaniu obiektów architektonicznych, Zeszyty Naukowe Politechniki Warszawskiej, Budownictwo, z. 4, s. 31-52.

Tonezzer L.

2002 Mittelalterliche Ziegelbrennöfen, [w:] Mittelalterliche Öfen und Feuerungsanlagen. Beiträge des 3. Kolloquiums des Arbeitskreises zur archäologischen Erforschung des mittelalterlichen Handwerks, red. R. Röber, Materialhefte zur Archäologie in Baden-Württemberg 62, Stuttgart, s. 101-114.

Wiewióra M.

2000 Zespót klasztorny kanoników regularnych $w$ Trzemesznie w świetle badań archeologiczno-architektonicznych, Archaeologia Historica Polona, t. 9, Toruń.

Wyrobisz A.

1961 Średniowieczne cegielnie $w$ większych ośrodkach miejskich $w$ Polsce, [w:] Studia i materiały z historii kultury materialnej, t. 10, Studia z dziejów rzemiosła i przemysłu, t. 1, red. Z. Kamieńska, Wrocław, s. 55-82.

1963 Budownictwo murowane w Małopolsce w XIV i XV wieku, [w:] Studia i materiały z historii kultury materialnej, t. 17, Studia z dziejów rzemiosła i przemysłu, t. 3, red. Z. Kamieńska, Wrocław.

1972 Próby znormalizowania wymiarów ceramiki budowlanej w Polsce w XVI wieku, Kwartalnik Historii Kultury Materialnej, R. 20, nr 1, s. 62-70.

Zagrodzki T.

1996 Czersk. Zamek i miasto historyczne, Warszawa. 
Żebrowski T.

1994 Kościól (XIV-poczatek XVI w.), [w:] Dzieje Mazowsza do 1526 r., red. A. Gieysztor, H. Samsonowicz, Warszawa, s. 327-361.

\section{POST-MEDIEVAL KILNS FOR FIRING CONSTRUCTION CERAMICS FROM THE AREA OF PLOŃSK}

Summary

The subject of the study are remains of a workshop producing construction ceramics, unearthed during archaeological excavations conducted in 2006-2008 in the area of Płońsk, in Masovian Voivodeship, on the southern bank of the Płonka River. It consisted of relics of two kilns, as well as several dozens of archaeological features containing production waste (mostly roof tiles fragments) and brick rubble.

Presented features are two rectangular kilns of different dimensions, adjacent to each other by one of the longer walls. They were oriented approximately along the north-south axis. In plan their entire outline was perceptible, in cross section remained two, maximally three layers of bricks and relics of stone foundations. The larger kiln (No. I) had external dimensions: $4.85 \mathrm{~m}$ of length and $4.40 \mathrm{~m}$ width, the smaller one (No. II) was $4.20 \mathrm{~m}$ long and $2.40 \mathrm{~m}$ wide and it was added to the eastern wall of the larger feature. In the kiln chambers, survived fragmentarily faces of the walls, made of bricks with finger grooves. On the outside, instead, stone foundations embedded in the natural sand were unearthed.

Apart from dimensions, the kilns also differed in construction. The larger one, No. I, had two firing chambers and three brick benches for stacking blank, i.e. bricks or roof tiles to be fired. The benches were placed along the longer walls of the kiln and in its central part. Inside, there were two hearths with width of $0.6 \mathrm{~m}$, along the entire length of the feature. The kiln No. II was smaller and had one hearth in the central part, $0.6 \mathrm{~m}$ wide. Based on its design, it was found that it was a two-phase feature, originally used as limestone kiln. Over the hearth of kiln No. II there were probably six brick arches at a distance of 0.25 to $0.3 \mathrm{~m}$ from each other. In the second stage, the device was rebuilt and its purpose was changed, i.e. it served as construction ceramics kiln.

On the site in question, apart from the kilns and adjacent pit, in total 62 features dated to the late Middle Ages and the Post-medieval period were unearthed. These were the economic pits (33), clay excavation pits (20), post holes (6) and hearths (3). They provided fragments of roof tiles, bricks, iron objects and animal remains.

From the inside of kilns and their surroundings 1916 fragments of ridge roof tiles of the monk-nun type were obtained. Many of them showed signs of scorch and deformation, hence they can be considered as waste created during the firing process. It was therefore assumed that the kilns were used to fire roof tiles.

Based on the obtained pottery, fragments of pot-shaped/bowl-shaped stove tiles and the analysis of the size of the bricks used for the kilns construction, as well as a coin from 1621 found in the kiln area, it was assumed that the beginning of kilns' functioning was at the end of the $15^{\text {th }}$ or the beginning of the $16^{\text {th }}$ century, while its end occurred in the early $17^{\text {th }}$ century. 
The workshop was located near Płońsk, hence it can be assumed that its production was intended for local or neighbouring customers. It probably operated to supply the development actions undertaken in the mid- $16^{\text {th }}$ century related to the construction or modernization of local churches - parish and monastic ones.

The kilns discovered in the Płońsk area complement a modest to date, collection of equipment for construction ceramics production, known from the Polish territory. They are also a valuable source for research on construction, former production and material culture at the end of the Middle Ages and the early Post-medieval period. 